\title{
COLUMN
}

\section{The Tooth of Time: James Smith of Jordanhill}

\author{
Paul F. Hoffman \\ 1216 Montrose Ave. \\ Victoria, BC, Canada, V8T 2K4
}

The successfully concluded Commonwealth Games in Glasgow brought to mind the remarkable Scottish yachtsman, antiquarian, architect, patron of learned societies, university president, conchologist, geologist, and Biblical scholar, James Smith (1782-1867) of Jordanhill. Born into a successful Glasgow merchant family, he discovered sailing and won many races as a youth, owned his own cutter, and sailed it frequently into Arctic waters over a span of 60 years. He was regarded as the father of the sport of yachting on the Clyde, and a sage of the history of yachting, yacht construction and navigation at sea. Whenever he sailed in coastal waters, he dredged for seashells, which he learned to identify under expert tutelage. He was 54 years old when he delivered his first geological paper (Smith 1836), which linked recent changes in relative sea level in Scandinavia and the British Islands with the enigmatic boreal Diluvium, or Drift, setting the stage for the controversy over the glacial theory that erupted in Switzerland the following year. He recognized the Arctic aspect of molluscan fauna indigenous to the drift of Scotland, and the appearance in beds of the same age in Sicily of fauna found today only in the waters of northern Europe (Smith 1839a). These were the first empirical proofs of a colder climate during the Drift period. They were the first proofs that global climate could get warmer, a phenomenon for which no physical theory then existed. Smith was not a major player in the ensuing glacial controversy because in those years he was sailing in the Mediterranean Sea, researching his most celebrated book (Smith 1848), a detailed and erudite reconstruction of the voyage and shipwreck of St. Paul, as described in the New Testament (Acts 27-28). Smith's meticulous scholarship-he read Greek and Latin as well as most Romance and Teutonic languages - and his intimate knowledge of the ships and navigation techniques of the Ancients, combined to authenticate both the voyage itself and Luke, its narrator, as an actual participant (Bruce 1959, p. 90). James Smith was born in Glasgow in 1782, the first-born (of five) of Archibald Smith (1749-1821) and Isobel Euing (1754-1855), both of whom had rural roots in western Sterlingshire, north of Glasgow (MacLehose 1886; Macnair and Mort 1908). His father's family had lived in the small parish of Strathblane for generations, but Archibald Smith, being a fourth son, migrated with his next older brothers to the Colony of Virginia in 1768 as a 19-year-old. He did well in the tobacco-driven economy, but when Virginia declared its independence from the British Crown in 1775, he returned to Scotland as the junior partner in the Glasgow-based trading company Leitch \& Smith, where he was instrumental in creating a major industry of trade with the West Indies. By 1800, his commercial success enabled him to purchase and retire to the estate of Jordanhill, overlooking the River Clyde west of the city. Isobel (Euing) Smith (1754-1855), from whom James Smith inherited his amiable disposition and sharp intellect, lived to the great age of 101 (Fig. 1). To the end, she took a keen interest in her son's career, and that of her grandson (his son), the mathematician and lawyer Archibald Smith, FRS (1813-1871), whose scientific work was in magnetism, geomagnetism, and the effect on the compass of the iron of a ship.

Educated at Glasgow Grammar School and the University of Glasgow, James Smith (Fig. 2) became a sleeping partner in his father's firm in 1809 at the age of 27. In the course of time, Leitch \& Smith became James and Archibald Smith \& Co., not Archibald the father but James' younger brother of the same name, whose business acumen gave James the freedom to indulge his own interests. A prodigious reader and book collector, James was married in 1809 to Mary Wilson (Fig. 3), the daughter of a book-seller and granddaughter of Professor Alexander Wilson (1714-1786), a distinguished astronomer in the University of Glasgow. They raised a large family, with seven daughters surviving infancy in addition to first-born Archibald, who in 1836 became the first Scotsman to be Senior Wrangler at Cambridge University. The list of also-rans for this coveted prize, given annually to the top undergraduate in mathematics, reads like a Who's Who in physics. The family moved to Jordanhill upon the senior Archibald's death in 1821. 


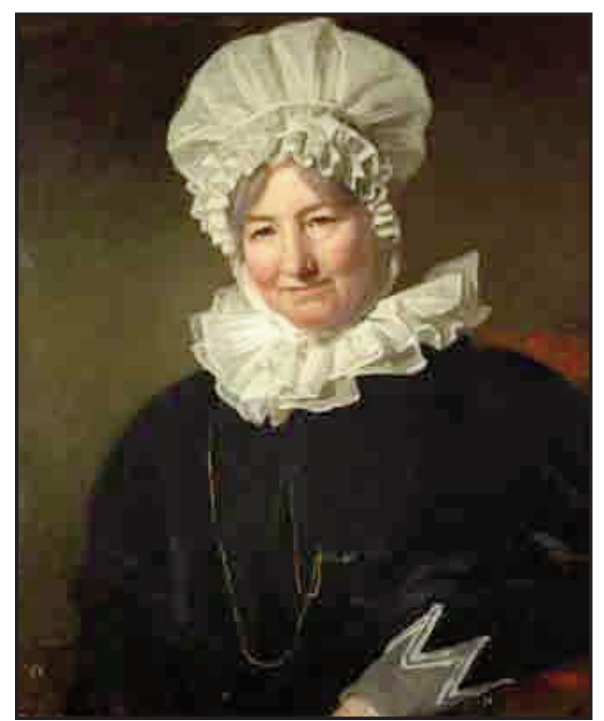

Figure 1. James Smith's mother, Isobel (Euing) Smith (1754-1855), age 56, a woman of "mental charms untaught to shine" who would closely follow the scholarly activities of her son and grandson (his son) until the age of 101. Oil painting by Glasgow artist John Graham-Gilbert (1794-1866), who, like James Smith, forsook his father's West Indies trading business for art. National Galleries of Scotland collection.

Smith's first voyage in his own vessel (Fig. 4), to West Greenland in 1806, cemented a life-long love affair with the sea. His presence in Greenland waters became so well known that Cape James, Cape Mary and Jordanhill Island in the Fjord Zone of East Greenland were named in his honour. Yachting as an organized sport dates back to the 1700's in Ireland and Great Britain, but organized racing on the Clyde began with the founding of the Royal Northern Yacht Club in 1824. The idea for the club, to unite yachtsmen in the North of Ireland and the West of Scotland, was conceived in the cabin of Smith's boat while at anchor in Belfast (Anonymous 1924). While his yachts were never large, his "singular talent for planning and arrangement always made his little ship the most comfortable and roomy of her size afloat" (MacLehose 1886). His architectural designs include Craigend Castle, the Govan Parish Church and an unexecuted scheme for a Crystal Palace at Park Circus in Glasgow's posh west end. As President (1831) of Anderson's University, founded in 1796 as an alternative to

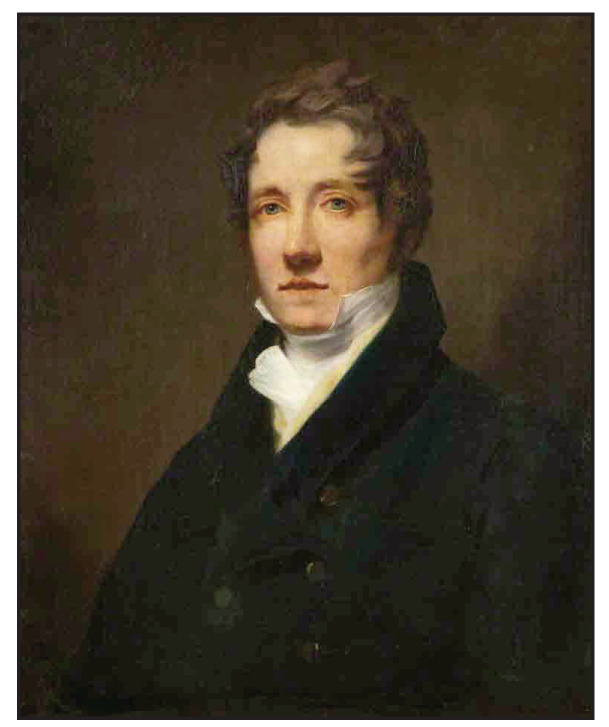

Figure 2. James Smith (1782-1867), age 27 , around the time of his marriage to Mary Wilson in 1809 . Oil painting by Edinburgh portrait artist Henry Raeburn (1756-1823). University of Strathclyde collection.

the University of Glasgow with an emphasis on "useful learning", Smith designed the Andersonian Museum (Fig. 5), once the public face of what is now the University of Strathclyde. He also renovated the mansion at Jordanhill and erected a mast on the grounds that gave a sense of scale to the rolling hills of the valley of the Clyde. His wide interests and gentle manner made him an ideal companion at sea, and he in turn learned much from the young naturalists who often accompanied him on his voyages, notably John Scouler (1804-1871), who explored the Columbia River system in the same years as the Lewis and Clark expedition (1804-06), and Edward Forbes (1809-1868, pronounced four-bees) who would confirm and extend Smith's paleoclimatic interpretation of the Drift fauna (Forbes 1846).

In Smith's day, it was common knowledge that the land is slowly rising out of the sea in many places along the coastlines of Scandinavia and the British Isles, while in other places the sea is slowly inundating the land. Raised beaches and drowned forests are conspicuous manifestations of these changes (Celsius 1743; Linnæus 1745; Correa de Serra 1799; Buch 1810; Fleming 1823; Lyell 1835; Bravais 1840; Chambers 1848; Jamieson

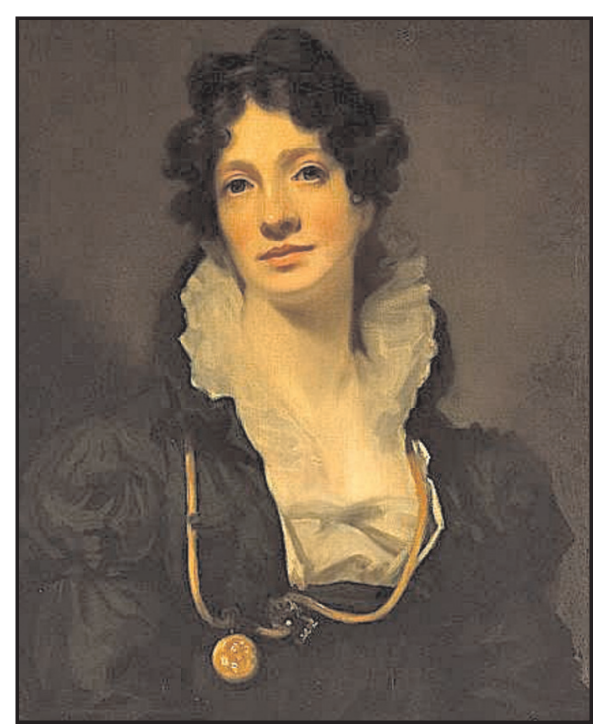

Figure 3. Mary Wilson (1789-1847), age 20 , around the time of her marriage to James Smith in 1809. Oil painting (duplicate) by Henry Raeburn (1756-1823).

1882; see also Wegmann 1969). Such phenomena were bound to attract the interest of a sailor, at a time when "the history of the Earth, next to that of the beavens, affords the most sublime subject of study that can be derived from physical science" (Buckland 1836, paraphrasing astronomer William Herschel 1830). As enigmatic as the sea level changes were the various landforms and surficial deposits that are characteristic, if not unique, to northern Europe and North America. Much was written about the origin of underfit streams, deep lakes, silled fjords, and polished bedrock surfaces that had been directionally striated and streamlined by a flowing medium that had evidently swept across the landscape unimpeded by the rises and falls of local topography (Chorley et al. 1964; Davies 1968; Cunningham 1977). Many believed that this medium was also responsible for the transportation of erratic blocks, some of which were enormous and demonstrably far-travelled, frequently standing remote from existing drainages (Buch 1817, 1819; Razumovsky 1819, 1829; Buckland 1821; Strangways 1821; Brongniart 1828; Bernhardi 1832; Sefström 1838; Charpentier 1841; Hitchcock 1841). Puzzling as well were deposits of boulder-clay, called till by farmers in parts of the Scottish lowlands, a term that Smith (1836) would add to the geolog- 


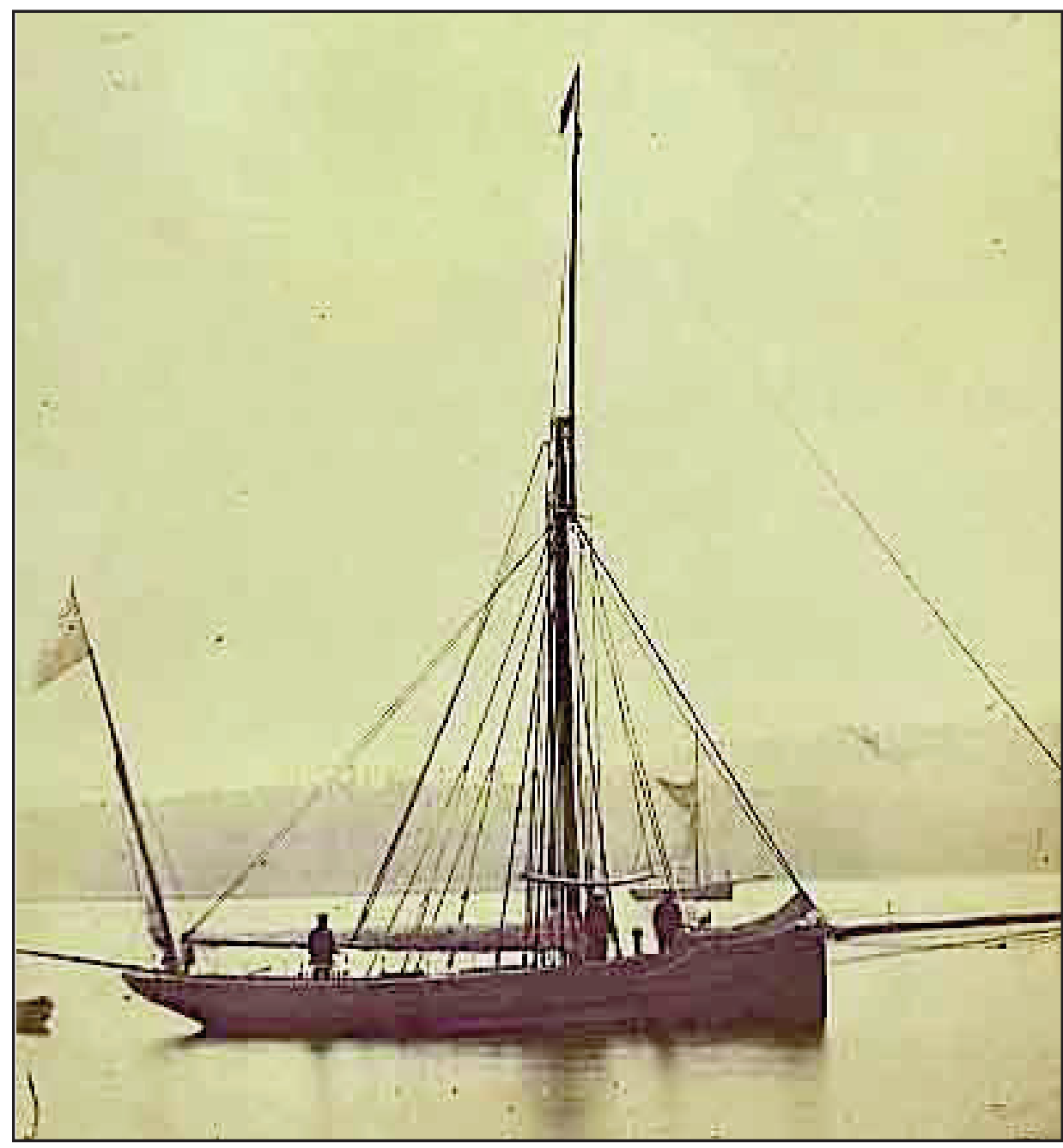

Figure 4. Smith's cutter, Wave, in 1863. Smith sailed and dredged sea-shells in the Arctic Atlantic seas for sixty years, 1806 to 1866, a period encompassing the rise of Quaternary geology (Fig. 7).

ic lexicon. It was paramount that this ensemble of comparatively recent phenomena be satisfactorily explained, Smith (1836) dryly observed: "As it belongs to one of the first steps in the descending series, every circumstance connected with it should be carefully observed and recorded, [in order] that researches into the more ancient formations may be conducted with greater success."

Three genetic theories for the above phenomena dominated geologic discourse in Britain in successive decades - the diluvial theory in the 1820 's, the northern drift theory in the 1830 's and the glacial nappe theory in the 1840's. Each theory had noble antecedents and a vigorous proponent (Rudwick 2005, 2008). In Britain, the leading proponent of the first and last theories was one and the same, William Buckland (1784-1856), the second reader in geology (1814-49) at Oxford University. Buckland's eccentricitieshe claimed to have eaten the flesh of every animal species known to manand his penchant for seeking common ground between conflicting perspectives, have tended to obscure his science and its significance (Rupke 1983).

In 1812, the Royal Society of Edinburgh heard a pair of lectures from their President, Sir James Hall (1761-1832), that challenged the strict actualism of his deceased friend James Hutton (1726-1797) and his followers, who held that it was 'unphilosophical' to invoke imaginary processes outside human experience to account for geological phenomena. Hall argued that familiar processes, like tsunamis, might scale up in magnitude beyond what any humans had survived to report, yet still be commonplace in the enormity of geologic time. In his first lecture, Hall (1814) reviewed the problem of erratic boulders and associated landforms in northern Europe and the Alps. The Alpine erratics, made famous by Saussure's Travels in the Alps (Saussure 1779-96), were ascribed by most savants to basin-scale outburst floods. [Hutton (1795) and his interpreter, mathematician John Playfair (1748-1819), had suggested earlier that the erratics were transported by glaciers, at a time when the Alps were higher than today (Playfair 1802). Playfair's protégé, physicist John Leslie (1767-1831), visited the Alps in 1796 and had inferred that vegetated moraines down to 3000 feet or more below the active glaciers mark the former extents of those glaciers at a colder time (Leslie 1804, note XXV, p. 536-541). Leslie's own protégé was the pioneer Scottish glaciologist James David Forbes (1809-1868).]

In his second lecture, Hall (1814) surprised his listeners by describing erratics, directionally-sculpted landforms, and striated bedrock pavements analogous to those in the Alps in the vicinity of Edinburgh itself, including the city's topographic and historic landmark, Castle Rock. Directional indicators showed conclusively that the abrasive agent had flowed from west to east, consistent with the transport of erratics. Hall proposed that a "diluvian wave", or mega-tsunami, generated by a sudden displacement of the sea-floor and more powerful than any historical tsunami, had swept across the entire country before discharging into the 'German Sea' (North Sea). Its abrasive power he attributed to rock debris entrained in sea-ice carried by the diluvian wave, and he predicted that two sweeps in opposite directions would be observed in the west of Scotland, the first associated with the primary wave and the second with the backwash of water that failed to surmount the inland ridge. Hall argued that mega-tsunamis, while outside human experience, must have occurred frequently over geologic time and should therefore be encompassed in a uniformitarian world-view. "I am a great friend of controversy," Hall wrote at the time, "and keep it up here [in Edinburgh] as much as I can" (Rudwick 2005 , p. 580). 


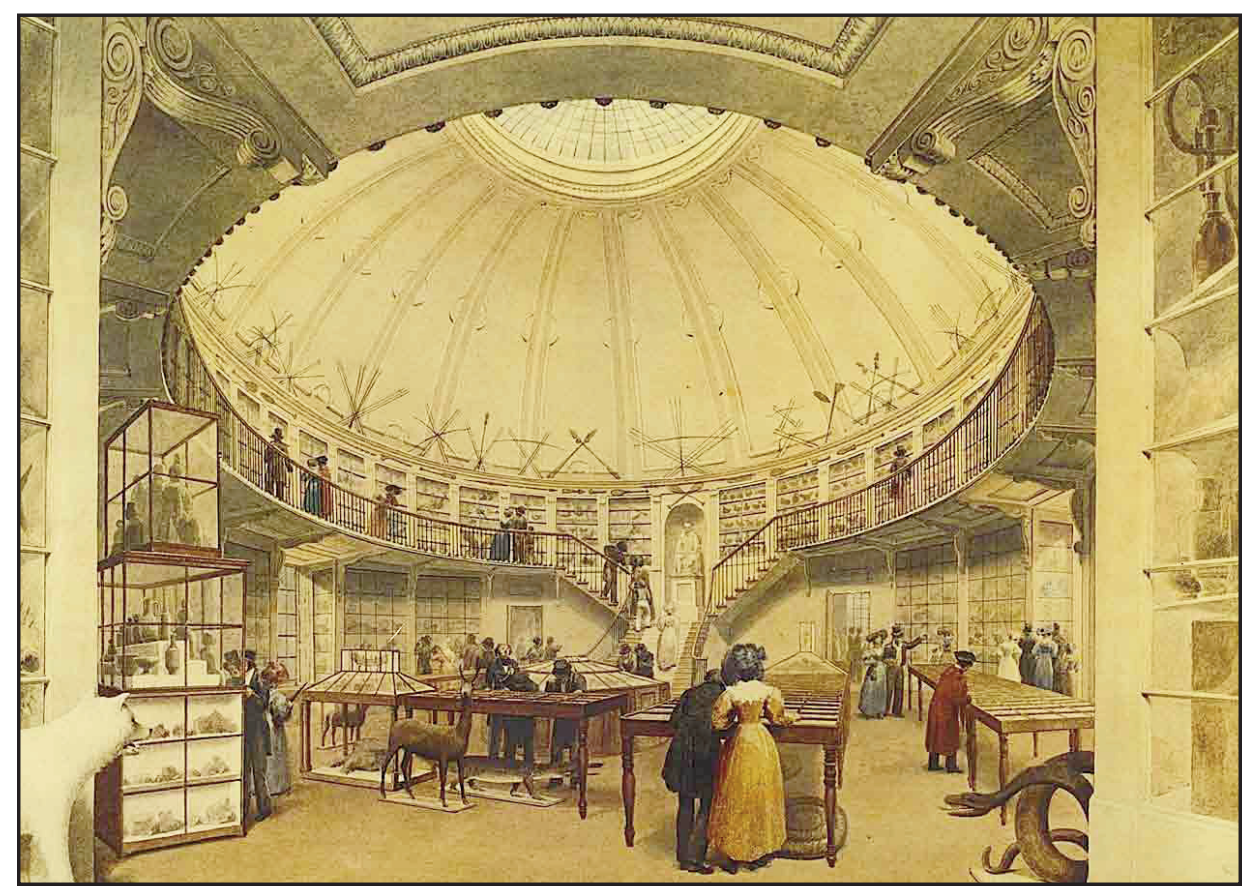

Figure 5. Interior of the Andersonian Museum, designed by James Smith in 1831 as the public face of Anderson's University, now the University of Strathclyde. It was founded in 1796 as an alternative to The University of Glasgow with an emphasis on 'useful learning'. Smith was President of the university in 1831. University of Strathclyde collection.

Buckland began lecturing in mineralogy at Oxford the year Hall's paper on diluvian waves appeared in print and a readership in geology was created to augment his meagre income five years later in 1819 (Rupke 1983). Like his contemporary, Adam Sedgwick (1785-1873) at Cambridge University, Buckland was an ordained minister and strove to ease the entry of geology into the religious universities (exclusively Anglican) of Oxford and Cambridge. His well-publicized inaugural lecture as reader (Buckland 1820) emphasized that no contradiction exists between the Mosaic account of Creation as an abode for humanity and the scientific investigation of worlds before Adam: "though Moses confines the detail of his history [in Genesis] to the preparation of this globe for the reception of the buman race, be does not deny the prior existence of another system of things, of which it was quite foreign to his purpose to make mention, as having no reference to the destiny or to the moral conduct of created man." According to Buckland (1820), the Mosaic flood is where the observations of geology and the revelation from Scripture intersect. "The two great points then, of the low [recent] antiquity of the buman race, and the universality of a recent deluge, are most satisfactorily confirmed by everything that has been brought to light by Geological investigations; and as far as it goes, the Mosaic account is in perfect harmony with the discoveries of modern science." Buckland's knowledge of surficial geology at this time was largely second-hand, but not for long.

Buckland's curiosity had been aroused by smoothly-rounded pebbles of hard quartzite, which were strewn among more angular stones in the hills and valleys around Oxford (west of London). Soon after his inaugural lecture (Buckland 1820), he traced their source to the Triassic New Red quartzpebble conglomerate, exposed in the Licky Hills southwest of Birmingham (Buckland 1821; see also Rudwick 2005). Recycling explained the anomalous rounding of the quartz pebbles - they were round to begin withbut a larger question arose: why were they shed southeastward as far as London, 100 miles away, rather than southwestward down the Severn River to Bristol Channel, reaching sea level in half the distance? To Buckland, the answer was clear: the quartz pebbles were carried by the universal deluge, which preceded the establishment of the present drainage system. He recommended (Buckland 1821) that deposits of the former and latter be distinguished, under the names Diluvium and Allwvium, respectively, following Strangways (1821).

This distinction was supported, for a time, by Sedgwick at Cambridge (Sedgwick 1825). Buckland spent the summer of 1820 on the Continent, where he visited the Quaternary volcanic area of the Auvergne (central France). U-shaped valleys in the higher parts of the Auvergne had long been a focus of debate over underfit streams, small streams in broad valleys. Were the streams larger in the past, or would small streams carve large valleys if given sufficient time? Buckland saw a dichotomy, reinforced by a striking contrast in morphological preservation between the younger and older volcanic groups. He had the answer: the older volcanoes had been ravaged by the deluge that cut the U-shaped valleys; the younger volcanoes are unscathed and the rivers occupy valleys not of their own making. The last point was corroborated on the south coast of Devon and Dorset in 1821, where Buckland was working on gently-dipping Secondary (Mesozoic) strata exposed in sea cliffs. He observed that numerous secondary valleys, oriented north-south, intersect the sea cliffs as hanging valleys (Buckland 1922a). These valleys could not have been cut by the streams that now occupy them because neither the streams nor the valleys are graded with respect to sea level. For Buckland, the hanging valleys had to be Diluvial valleys. He did not speculate on the ultimate cause of the deluge.

Buckland's big break came in the Fall of 1821 with news that a cave rich in exotic bones had been opened over the summer in Yorkshire, and was being plundered by local collectors (Buckland, 1822b, 1823; see also Rudwick 2005). Some specimens had already been sent to London, where most were identified as the powerful jaw bones of hyaena, but larger than the modern species. Despite the lateness of the season in the north of England, Buckland set out for the Kirkdale cave and in December made a series of collectively astounding obser- 
vations. Most of the bones were of hyaena and small water-rats, but the cave also yielded bones of pachyderms (elephant, rhinoceros, hippopotamus and horse), ruminants (ox and three species of deer), other carnivores (tiger, bear, wolf, fox and weasel), other rodents (hare, rabbit and mouse), and five species of birds (raven, pigeon, lark, a small duck and an unassigned thrush-like species). The large species were surprising because the cave's only entrance was far too small to allow such beasts to enter, and no opening existed in the roof through which they could have fallen. Nearly all the bones were fragmented and many bore tooth marks, identifiably hyaena. Buckland reasoned that the cave was a hyaena den and that its residents habitually dismembered their prey in order to eat in the safety of their den. When large game was scarce, the hyaenas had subsisted on water-rats inhabiting a nearby lake. There was a disproportionate abundance of solid foot and hand bones, of minimum nutritional value. Not at risk to earlier collectors were vast quantities of fecal droppings, to which Buckland predictably devoted special attention. Experiments were carried out with captive hyaenas on 'Kirkdale' diets for intricate comparison of their feces as a test of the hyaena-den hypothesis.

Buckland knew that the age of the bones was critical. Upon excavation, he determined that the bedrock floor of the cave was largely covered by stalagmite, which had encrusted some of the bones. Most of the bones lay above the stalagmite and were buried by up to a foot of mud. The mud was capped by a second level of stalagmites, which match the stalactites on the roof of the cave. Buckland estimated that the interval of stalagmite growth following mud deposition lasted no more than several thousand years. He inferred that the hyaenas were driven away and the mud deposited by the universal deluge. The bones, therefore, were the hyaena's pick of antediluvian faunal diversity (Fig. 6). Buckland had added a new dimension, paleoecology, to the study of Cuvier's 'former worlds' (Rupke 1983; Rudwick 2005). A natural showman, the Kirkdale cave for Buckland was a dream come true. On February 21st, less than

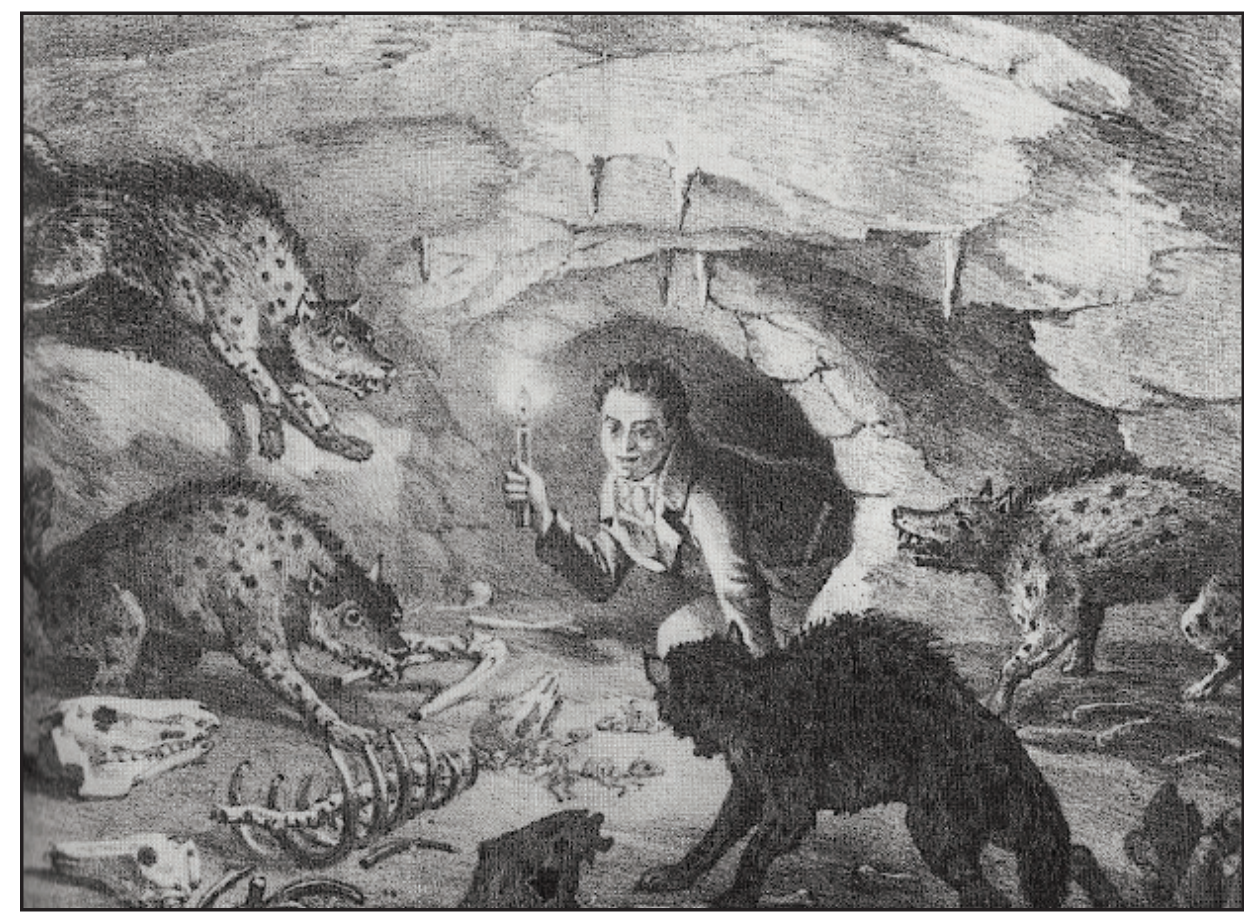

Figure 6. William Buckland entering the den of extinct pre-Diluvian haenas at Kirkdale in Yorkshire (northeast England) in 1821, in a caricature by Buckland's friend and fellow-geologist William Coneybeare (Rudwick 1992).

three months after he arrived in Kirkdale, he read and placed before the Royal Society of London a 65-page paper with 12 plates (Buckland 1822b). It brought Buckland the Copley Medal for 1822, the Royal Society's most prestigious award, the first geologist to be so honoured. (Like other such awards, it used to be given for work done in the past year, then in the past decade, and now for work done half a century ago. At this rate, the selection criterion will soon be longevity itself.)

In the same year, Buckland's friend, supporter and geological superior, William D. Conybeare (1787-1857), published Outlines of the Geology of England and Wales (Conybeare and Phillips 1822). In describing the Diluvial they wrote: "In these deposits, and almost in these alone, the remains of numerous land animals are found, many of them belonging to extinct species, and many others no longer indigenous to the countries where their skeletons are thus discovered." Here were the seeds of destruction for Buckland's Biblical flood connection. In 1823, Buckland republished his Diluvial papers as a book, expanded with descriptions of cave faunas in Germany and throughout England, and of evidence for Diluvial action on other continents (Buckland 1823). The book, Reliquiae Dilu- vianae (Relics of the Flood) was both a public success and a lightning rod for criticism from all directions (Page 1969). The most serious criticisms were the absence of human remains in the Diluvium (human creation predated the Genesis flood) and the extinctions of boreal megafauna (should have survived in Noah's Ark). Human remains had in fact been found in caves with antediluvial bones, and Buckland discussed them in his book. But he was rightly cautious about grouping cave fossils that lacked proper stratigraphic control and favoured an Alluvial age for human remains in caves, despite the difficulty it raised for the Diluvial theory. He tried to deflect criticism of the age discrepancy by suggesting that while humans existed before the universal deluge, they had yet to populate northwest Europe. Decades later, the evidence for antediluvial humans in northwest Europe was confirmed (Boucher de Perthes 1857; Prestwich 1860; Lyell 1863; see also Grayson 1983): there was no conflict with Genesis on this point after all, but Buckland and other Diluvianists did not know that the facts were actually on their side.

Either way, the extinction problem was the more intractable one, and 
there was hidden danger there as well as the obvious one. John Fleming (1785-1857), a Scottish anti-Diluvianist (aka Fluvialist) who had recently published on drowned forests in the Firth of Tay (Fleming 1823), argued that the Diluvial fauna of Buckland's hyaena den had survived into Alluvial times, when they were extirpated not by cold but by the expansion of human civilization (Fleming 1824). He pointed to the extinct giant deer, Megaceros (aka Irish 'elk'), the bones and antlers of which occur in the Alluvial peat-bogs of Ireland and the Isle of Man (Forbes 1846). A Presbyterian minister, Fleming's intent was to sunder the connection between science and religion, which could only produce, in his words, "Philosophia phantastica, Religio haretica." Yet, survival of antediluvian fauna through the universal deluge offered to reconcile the Diluvial theory with Genesis. However, in the absence of a mass extinction, the Diluvium in different areas could not be correlated and consequently the basis for the universality of the deluge would evaporate. Buckland was trapped. Sedgwick withdrew his support for the Diluvial theory in his presidential addresses to the Geological Society (Sedgwick 1830, 1831), as did Buckland himself in his masterpiece, the Bridgewater Treatise of 1836 (Buckland 1836). He continued to treat the Diluvium and Alluvium as distinct in age and origin, but if the Diluvium was the product of a universal flood, it was not the flood of Genesis, but an older one. No geologist of the stature of Buckland or Sedgwick would attempt again to link geology and Genesis until Bill Ryan and Walter Pitman in the modern era (Ryan et al. 1997; Ryan and Pitman 1998).

With the demise of Diluvialism, another old idea was revived to take its place, this time by the neo-Huttonian geological correspondent, Charles Lyell (1797-1875). Fifteen years younger than James Smith and thirteen younger than Buckland, Lyell promoted what came to be known as the iceberg drift theory, although at first it didn't involve icebergs at all. In 1780, Johann (Karl Wilhelm) Voigt (1752-1821), a recent graduate of Werner's Mining Academy (Bergakademie) at Freiberg, began a geological survey of central
Germany in the course of which he realized that boulders of granite and porphyry in the north of Thuringia did not have a local source (Engelhardt 1999). He reasoned that they were of northern origin because of their distribution within the state. As to their mode of emplacement, he noted that fishermen had observed stones being rafted in ice flows from one side of a lake to the other over Spring breakup. By extension, he postulated that as the ocean waters slowly receded over geologic time and the continents emerged (a Wernerian theory, and not a bad one on the planetary time scale), landfast sea ice on the Scandinavian coast, as well as the boulders it froze onto, would be rafted southward annually during Spring breakup under the influence of prevailing winds (Voigt 1785). The image of high seas, cold winds and invasions of pack ice into central Europe captured the imaginations of contemporary artists and writers (Rudwick 1992; Engelhardt 1999).

In 1804, a 38-year-old highschool math and science teacher in Berlin, Erhard Wrede (1766-1826), published a new wrinkle on ice rafting of erratic boulders (Wrede 1804). Like Voigt, he envisioned sea ice rafting to have occurred at a time when sea level was higher than present, to accommodate the enormous size of some boulders. Unlike Voigt, he imagined that sea level could change in either direction. He suggested that if the solid Earth shifted with respect to its rotation axis, those areas on the globe that moved equatorward would experience a sea level rise due to the equatorial bulge, while areas that moved poleward would undergo sea level fall (Rudwick 2005, p. 572; see also Wegener 1929, chapter 8). In principle, Wrede's suggestion is valid although the relative sea level change is transient, caused by the difference in response time of seawater and the Earth's mantle. It is therefore strongly dependent on the rate of polar migration (Mound and Mitrovica 1998).

In volume 3 of the first edition of Principles of Geology, Lyell devoted only two pages $(0.4 \%)$ to striated pavements and Alpine erratics, brushing aside the mega-tsunami interpretation disparagingly as "a simple solution of every difficult problem" (Lyell 1833, p. 148).
True to his word, he substituted for each problem a complex solution: for striated pavements, "the friction of blocks rolled along the floor of the ocean before the country emerged from the deep"; for Alpine erratics-take a deep breath—earthquake-triggered rockfalls onto glaciers, which collapsed into dammed lakes causing them to burst, sending cascades of water and rock-bearing icebergs into an arm of the sea, now occupied by the Swiss central valley (Lyell 1833, p. 149-50). Three years later, just months before James Smith's paper on Scottish tills was read in London (Smith 1836), Lyell delivered the annual Presidential address to the Geological Society (Lyell 1836). He now endorsed Murchison (1836) in recognizing the "northern drift" as a distinct class of surficial deposits, distinguished by its spatial and compositional affinity with erratic boulders of northern origin, and by the infrequent occurrence of marine molluscan shells of existing species (see also Murchison 1839). Their distribution and lack of extinct species implied that much of the north country was below sea level in the geologically recent past (Lyell 1836). As to its origin, Lyell steered in the direction of Voigt (1785) and Wrede (1804), citing reports of rock and soil rafting by ice islands of winter sea ice in Scandinavia, the Labrador Sea and the Gulf of St. Lawrence. He noted the nascent glacial theory for the emplacement of Alpine erratics, recently put forward by Charpentier $(1835,1836)$. However, Charpentier (1786-1855) postulated that the Alps were even loftier than today when the erratics were emplaced, leading Lyell to dismiss the glacial theory as having no relevance to British geology.

Iceberg rafting, as distinct from entrainment in sea ice, became Lyell's principal means of accounting for diluvial phenomena beginning with the second edition of The Principles, in which volume 3 on historical geology was split off as a separate series (Lyell 1838). The new emphasis on iceberg rafting is mainly attributable to one Charles Darwin (1809-1882), then not yet 30 years old. After noting that erratics occur in both hemispheres but only in higher latitudes, implicating a colder climate in their origin, Lyell (1838) cited Darwin to the effect that 
glaciers reach down to the sea at the heads of all the sounds on the west coast of South America at latitudes equivalent to the Swiss Alps $\left(46^{\circ} \mathrm{S}\right)$. Icebergs calved from these glaciers, charged with boulders of granite, were observed floating seaward more than $30 \mathrm{~km}$ from the head of the sound (Darwin 1840, p. 283-4). Six months earlier (austral summer of 1833-34), Darwin had carefully surveyed vast terraces capped by gravel at different elevations in Patagonia east of the Andes (Darwin 1840, p. 201-207; see also Herbert 2005). Ascending the Santa Cruz River $\left(\sim 50^{\circ} \mathrm{S}\right)$, he had encountered angular blocks of schist and granite up to $100 \mathrm{~km}$ from the foot of the mountains (Darwin 1841, 1840, p. 224). Now he had the explanation: icebergs had rafted the blocks far from their glacial sources at a time when the Patagonian lowlands were submerged; subsequent stepwise uplift had raised the terraces and their oversize cargo to their present elevations (Darwin 1841, 1840, p. 284). The same was true on the west side of the Andes, where erratics are spread along the coast as far north as $42^{\circ} \mathrm{S}$ (Darwin 1837, 1839a, 1841). This explanation resonated with Lyell because it dovetailed with his view that most climate change was regional, not global, caused by interchange between areas of land and sea (Lyell 1830: see also Fleming 1998). Darwin, for his part, recognized that, if iceberg rafting was the general cause of erratics and associated phenomena in the northern hemisphere (Darwin 1839a), large parts of North America and Europe had been subsequently uplifted. Consequently, other large areas of the Earth's crust must have recently subsided, exactly as required by his theory for the growth of coral reefs and atolls in response to subsidence of the sea floor under much of the tropical western Pacific and central Indian oceans (Darwin 1842a).

As a measure of the efficacy of iceberg rafting, Lyell often cited the occurrence of Andean erratics on the Island of Chiloe $\left(42-43^{\circ} \mathrm{S}\right)$, which is separated from the mainland by the Gulf of Corcovado. The erratics are limited to the east side of the island, consistent with iceberg rafting from the mainland (Darwin 1841). Little did Lyell or Darwin know that at the Last
Glacial Maximum, the Gulf of Corcovado was filled by glacial ice and the edge of the Andean (Chilean Lake District) ice cap was situated on the Island of Chiloe itself (Hollin and Schilling 1981; Harrison 2004; see also Evenson et al. 2009). Although the space Lyell devoted to the northern drift in his major works waxed and waned with the fortunes of the glacial theory (Fig. 7), it was not until the 1860's (Lyell 1863, 1865) that he was finally persuaded that glacial ice may have played a significant role in its origin (Boylan 1998). Lyell was less intemperate than Roderick Murchison (1792-1871) in his opposition to the glacial theory (Murchison 1842a, b), but he thought it no less inconceivable that the British Islands would have been glaciated at a time when they were mostly submerged (Lyell 1863).

Darwin, who subsequently flipflopped over the glacial theory, added an intriguing footnote in Voyage of the Beagle (Darwin 1840, p. 294-5). He credited Jens Esmark (1763-1839) for recognizing that glaciers in Norway once descended to lower elevations than they do today, indicating a colder climate. Indeed, Esmark's paper, originally published in Danish (Esmark 1824), was the progenitor of the glacial theory (Andersen 1992). Darwin would likely have encountered it in his natural history course at the University of Edinburgh in 1826-27, taught by Robert Jameson who was responsible for having Esmark's paper presented and published in English translation the same year (Esmark 1826; see also Worsley 2006, 2008). Esmark, another graduate of Werner's Bergakademie (and an older classmate of Alexander von Humboldt and Leopold von Buch), was professor of mining sciences at the new University of Christiania (Oslo) and a mountaineer, familiar with the active glaciers of western Norway. In the second half of his paper, Esmark described a 25-m-high transverse moraine (locally named Vassryggen) and associated sandur (outwash plain) that dammed a deep lake within a U-shaped valley at low elevation near Stavanger, on the southwest coast of Norway. Esmark interpreted the moraine as the former termination of a glacier that cut the steep-walled bedrock valley and lake basin. Analo- gous landforms occur throughout Scandinavia as well as the Alps, he observed, "in every country, whether it be mountainous or flat, we shall find similar traces of the operation of masses of ice." In Norway, he wrote (Esmark 1826), where "the mountain precipices are often three, four, to five thousand feet high, and the valleys over which they hang are likewise several thousand feet in breadth, it must be a matter of astonishment to think of such valleys as being filled with ice to the extent of several miles. This ice must have stretched a long way into the sea, and, on its thawing, large masses must have broke loose, and gone out to sea as we find takes place now in the polar regions." To my knowledge, Darwin's footnote and an allusion by Murchison (1836) are the only references to Esmark's theory by an English-speaking author during the entire controversy over the glacial theory (Fig. 7). Rudwick (1969) attributes this neglect to the cosmogonic overtones in the first half of Esmark's paper, but this hardly absolves British historians, viewing the glacial controversy from a century's perspective (e.g., McCallien 1941; North 1943; Chorley et al. 1964; Hansen 1970). With the exception of Herries Davies (1969), Rudwick (1969), Cunningham (1990) and especially Peter Worsley $(2006,2008)$, they largely ignored Esmark's (1826) hypothesis and its extensions to northern Germany (Bernhardi 1832).

For his part, Darwin (1840) expressed admiration for Esmark's hypothesis regarding a colder climate. It would account for Darwin's presumed iceberg-rafted erratics on the Island of Chiloe at latitude $42-43^{\circ} \mathrm{S}$, where no Andean glacier touched the ocean even in Darwin's day. Darwin was skeptical, however, because "organic remains [fossils] of that epoch, instead of a former period of refrigeration, would have indicated a climate of a more tropical character; - a conclusion, which may be deduced from plain evidence" (Darwin 1840, p. 295). Darwin's hasty judgement underscores the importance of James Smith's work on the paleoclimatic, as well as the biostratigraphic, significance of the molluscan fauna indigenous to tills in Scotland (Smith 1836, 1839a-d), which demonstrated that Darwin was misinformed regarding the climate of the Drift period. 


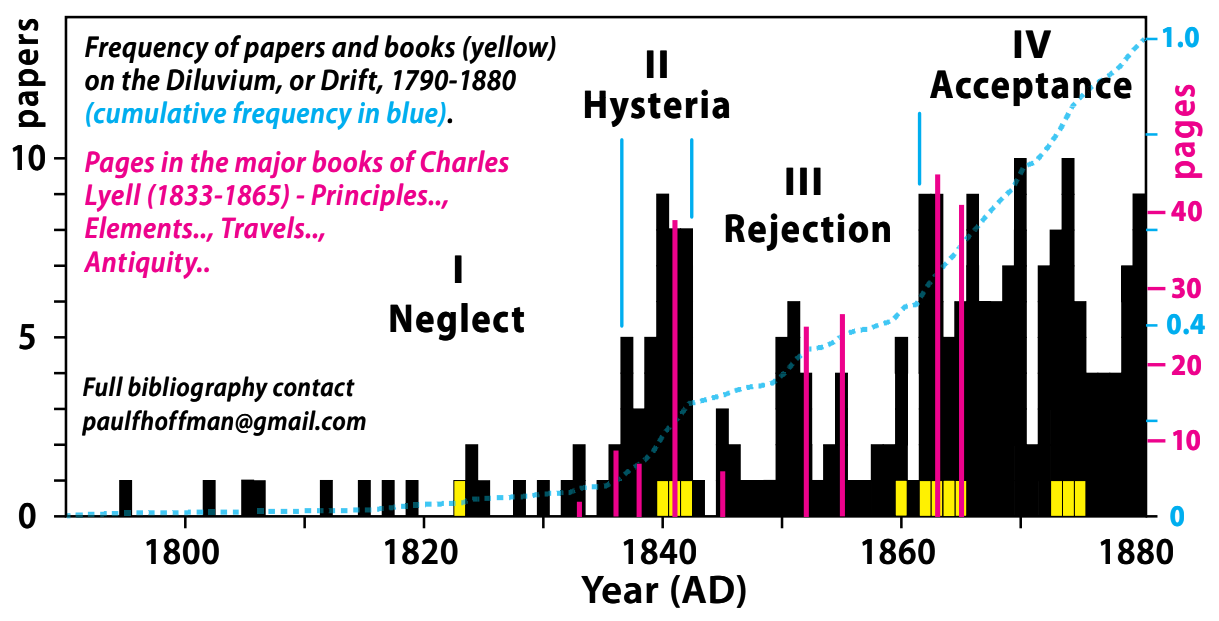

Figure 7. Histogram of publication frequency of papers on the Diluvium, or Drift, between 1790 and 1880, illustrating the four stages of the controversy over the glacial-nappe theory of Esmark, Bernhardi and Agassiz. Magenta bars give the numbers of pages Charles Lyell devoted to the topic in his major works. Lyell rejected the theory outright until 1863.

James Smith was no novice when he read his first paper to the Geological Society of London in November 1836, "On indications of changes in the relative level of Sea and Land in the West of Scotland" (Smith 1836). Already a Fellow of the Royal Society of London, he had been elected a Fellow of the Geological Society six months earlier. His paper was motivated by Lyell's claim of ongoing emergence on the coast of Sweden (Lyell 1835), presented orally at the British Association meeting of 1834 in Edinburgh (Smith 1862b). Smith began by succinctly describing the gross twofold stratigraphy of superficial deposits in the Clyde River basin. The lower division, he wrote, "in some districts called "Till", consists of stiff unstratified clay, confusedly mixed with boulders." The distinction of till as a stiff clay is interesting: if the stiffness indicates dewatering under the load of an ice sheet, then till according to Smith's definition is a strictly subglacial deposit. "It rarely contains organic remains, but stags' horns, tusks, and bones of the elephant have been found in it in the bed of the Union Canal in Kilmarnocke," he continued, "and remains of the elephant are associated with marine shells at [nearby] Kilmaurs in Ayrshire." The upper division "is composed of finely laminated clay, overlaid by sand and gravel; and marine remains of existing species occur in every part of it, but most abundantly in the clay. A very great proportion of the species of shells, amounting in all to about 70, abound in the present seas; ... on the other hand, some of the species have become very rare, if not extinct with reference to the coast of Scotland."

On account of the high proportion $(\sim 90 \%)$ of living molluscan species, Smith (1836) assigned both deposits to the Newer Pliocene, following Deshayes (1831) and Lyell (1833, Appendix I). The marine shells typically occur 9-12 $\mathrm{m}$ above present sea level, and they are indigenous, based on manner of preservation, not swept in by violent action (Smith 1836). He marshalled his own observations and those of many others, finding in time that indigenous marine shells occur as much as $156 \mathrm{~m}$ above present sea level and that two discrete tills are separated by stratified drift (Smith 1850). Smith believed that the land was lower, relative to sea level, but stationary while the clays were deposited, which he estimated from the size of their terraces to "have greatly exceeded 2000 years." While he compared the subsequent rise of the land with that described by Lyell (1835) in Scandinavia, Smith $(1836,1839 \mathrm{c})$ observed that "in Scotland, the Roman [142 A.D.] wall, which crosses the island from sea to sea, was built at both ends with reference to the present level of the sea." Unlike Lyell (1835), Smith found it "bighly probable, that no changes of level have taken place since the British islands have been tennanted by man" (Smith 1839c).
Lyell (1840a) would later "adopt" (without attribution) the term till, for unstratified boulder clay, and also Smith's twofold division in describing the Boulder Formation or Drift exposed on the Mud Cliffs of the coast of Norfolk (England). He added two important observations: the stratified and unstratified drifts are partly intermingled, and on compositional grounds both have a common (northern) provenance (Lyell 1840). Lyell had flirted with the term Pleistocene as a substitute for Newer Pliocene in the 1939 French translation of his Elements of Geology (Farrand 1990), but he shunned the term- the concept of global climate change being anathema to himfrom 1840 until the $1873\left(4^{\text {th }}\right)$ edition of The Antiquity of Man, two years before his death. Farrand intimates that Lyell abandoned the term Pleistocene because of confusion created by Forbes' (1846) modification of its definition, but Lyell had already dropped the term six years earlier.

Smith updated his paleontological results at the 1837 British Association meeting in Liverpool (Smith 1837), but 1839 would be the year of his signature contribution to science, and one of personal tragedy. By then, Smith's inventory of molluscan shells indigenous to the drift deposits of the Clyde Basin included 190 marine and 57 terrestrial species (Smith 1839a). Of these, $89 \%$ still existed in British waters. Of the remaining 28 species, three quarters were extinct or unknown in the modern ocean. The seven extant species that no longer inhabited British waters all flourished on the colder coasts of Newfoundland and Labrador, Greenland, Iceland and even Spitsbergen, 1,000 km north of the Clyde (Fig. 8). The drift was clearly associated with a colder climate and molluscan fossils held the first empirical evidence of this, independent of theories for the emplacement of the drift itself (e.g. Esmark 1824). In 1839, Smith's extended reports were published in Edinburgh (Smith 1839c, d) and he read two papers at the Geological Society of London (Smith 1839a, b), the first "On the Climate of the newer pliocene tertiary period" and the second in which he endorsed "Lyell's proposed pleistocene system." The last paragraph of the first paper, almost a footnote, contains 


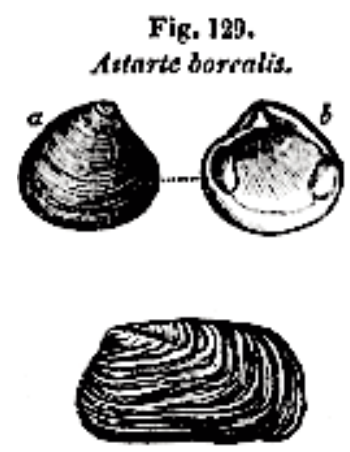

Fig. 191. Sartanta rugasa.

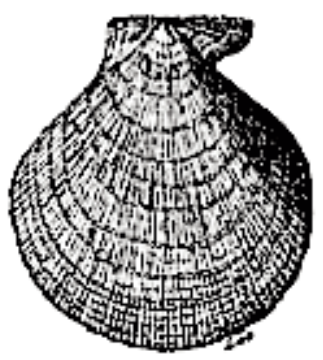

Filg. 132. Pecten fsiendicus.
$\mathrm{Fig}_{\mathrm{g}} 130$.

Zeda aldonga.

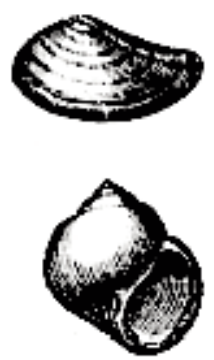

Fig. 133. Natica clausa, Trophon clathratum.

Figure 8. Cold-water molluscan fossils from the Newer Pliocene drift of the Clyde Basin, in the west of Scotland (Lyell 1865, p. 153). James Smith showed that these species are absent in Scottish waters but flourish off Newfoundland and Labrador, Greenland, Iceland and Spitsbergen, implying a colder climate in Scotland during the drift period (Smith 1839a). At the time, there was no physical theory for global climate warming and geological evidence was taken as being consistent with regionally reversible but globally monotonic cooling.

a hugely important additional observation. He has found in the Newer Pliocene of Sicily, "several species now found living only in more northern European seas; and he infers from them, that the climate of Sicily was at one period colder than it is at present" (Smith 1839a). Newer Pliocene to Recent warming in northern Europe alone could have been a regional phenomenon, as Lyell (1830) believed; contemporaneous warmings in northern Europe and the Mediterranean implied a supra-regional, presumably global, climate change.

In 1839, there was no physical theory for global warming. At the turn of the century, the late Edinburgh physicist John Leslie (1867-1831) had pointed to the retreat of Swiss moraines as evidence for global warming "due to the accession of solar radiation" (Leslie 1804, p. 180-182, 536-541). But his theory had been discredited by the discovery of infra-red radiation and the recognition by his contemporary Jean-Baptiste Joseph Fourier (1768-1830), that the Earth is emitting invisible long-wavelength radiation that exactly balances the energy it receives from sunlight. In a fascinating essay on climate, Fourier $(1824,1827)$ argued that as hot bodies emit more heat than cold ones, the Earth, if it were too cold, would emit less energy than it received and would consequently warm up until radiative equilibrium was established. Conversely, if the Earth were too hot, it would emit more ener- gy than it receives and would consequently cool down until energy balance was restored. According to Fourier, the Earth's climate is self-adjusted to be in radiative energy balance with the Sun. As the Sun is a large object that radiates far more energy than it receives, it must therefore be cooling and emitting less and less energy over geological time. That solar luminosity has in fact been steadily rising, due to thermonuclear processes, would remain unknown until 1939. Secular cooling was seen as consistent with paleobotanical evidence that Late Cretaceous and Eocene temperatures were warmer than more recent periods in most areas, and with historical evidence that the Medieval Period was warmer than the Little Ice Age, which was rapidly intensifying toward its last maximum in the decades following Fourier's 1824 essay on climate (Holzhauser et al. 2005). Smith's (1839a) inference that significant global warming had occurred in the geologically recent past was therefore a challenge both to climate physics and Lyellian geology (Rudwick 1969).

For Smith personally, his report on the Sicilian fossils (Smith 1839a) had harrowing circumstances. That winter, two of his younger daughters had contracted tuberculosis at school in London. Despite moving with their parents to the island of Madeira in the subtropical eastern Atlantic, both children succumbed to the disease. For the health of their youngest daughter, the family lived in Gibraltar and Malta for the next five years, returning to Jordanhill in 1846, where Mary Smith herself died of pneumonia the following year. It was during those years in the south of Europe that Smith undertook the research leading to The Voyage and Shipwreck of St. Paul (Smith 1848).

In September of 1840, the

British Association held its annual meeting in Glasgow. Smith was a cochair of Section C (Geology and Physical Geography) but, given his circumstances, played a subordinate role (Smith 1840). The appearance of Louis Agassiz (1807-1873) of Neuchâtel was a highlight of the meeting (Agassiz $1840 \mathrm{~b}$ ). The young Swiss was greatly admired in Britain, as elsewhere, for his ground-breaking research on fossil fish. He remains the youngest ever recipient of the Wollaston Medal (in 1836 at age 29), the highest award of the Geological Society of London. Agassiz was a recent convert to the glacial-nappe theory, which held that northern Europe and North America were formerly covered by dynamic ice sheets (nappes). He had precipitated a torrent of criticism with his surprise Presidential address at the 1837 meeting of the Swiss Natural Science Society at Neuchâtel (Terrisse 1931).

Expected to speak on fossil fish, he instead expounded on the glacial theory, which at the time was neither new nor accepted in Switzerland, and which Agassiz linked with the extinction of a strictly pre-human boreal fauna (Agassiz 1837, 1840a; see also Evans 1887; Wright 1898; Zittel 1901; Carozzi 1966). Undaunted by criticism, Agassiz had taken his message to France (Agassiz 1838-39) and had mounted a research program on active glaciers in the Alps, knocking heads with the Scottish glaciologist James David Forbes (Cunningham 1990). The 54year-old William Buckland had gone to Switzerland in 1838 to discourage Agassiz's glacial theorizing (Rupke 1983), but was himself won over by the remarkable homology between diluvial phenomena and those on display around active glaciers (Agassiz 1840a). It was much to the old diluvialist's credit that he quickly became the most vigorous proponent of the glacial theory in Britain, inviting Agassiz to 
the Glasgow meeting coincident with the publication of his impressive report on active and former glaciers, Études sur les glaciers (Agassiz 1840a; see also book reviews by Forbes 1842; Maclaren 1842; Murchison 1842; Rudwick 1969).

After the meeting, Agassiz and Buckland toured the Grampian Highlands searching for signs of glaciation (Davies 1968). Knowing what to look for, they saw them everywheremoraines, cirques, striated pavements and U-shaped valleys. At the northern foot of Ben Nevis, they visited the Parallel Roads of Glen Roy, then arguably the most famous and problematic natural phenomenon in the country (Fig. 9). Three terraces, the highest $\sim 350 \mathrm{~m}$ above sea level, had previously been interpreted as the shorelines of an ancient lake (MacCulloch 1817; Dick 1823; Mackenzie 1835), but there was scant evidence of the required dam at the mouth of the glen (Fig. 10). The previous year, Charles Darwin had published a long paper reinterpreting the terraces as uplifted marine shorelines in light of his experiences in Patagonia and southern Chile. The paper (Darwin 1839) got him elected to the Royal Society, but has subsequently gained notoreity as a blunder (Barrett 1973; Rudwick 1974; Herbert 2005). In 1840, Agassiz looked into the glen and immediately saw an ice-dammed lake, just like the famous Märjelen See (Lake), which was dammed by the Aletsch Glacier in Valais (Fig. 11) and was illustrated by a lithograph in Études sur les glaciers (Agassiz 1840a, Plate 12). Agassiz's interpretation of the Parallel Roads was fully vindicated, but only after the acceptance of the glacial theory twenty years later (Jamieson 1863; Prestwich 1879; Livingston 1906; Peacock 1970; Sissons 1979).

Following the tour with Agassiz (who went on to Ireland to look at a fossil fish collection), Buckland went directly to see Lyell, who was staying at his father's estate in Strathmore, east of the Grampians (Davies 1968). Together, they identified what they thought were moraines in nearby Forfarshire and, for a few months, Lyell too was converted to the glacial theory (Boylan 1998). Buckland arranged for all three, Agassiz, Lyell and himself, to present

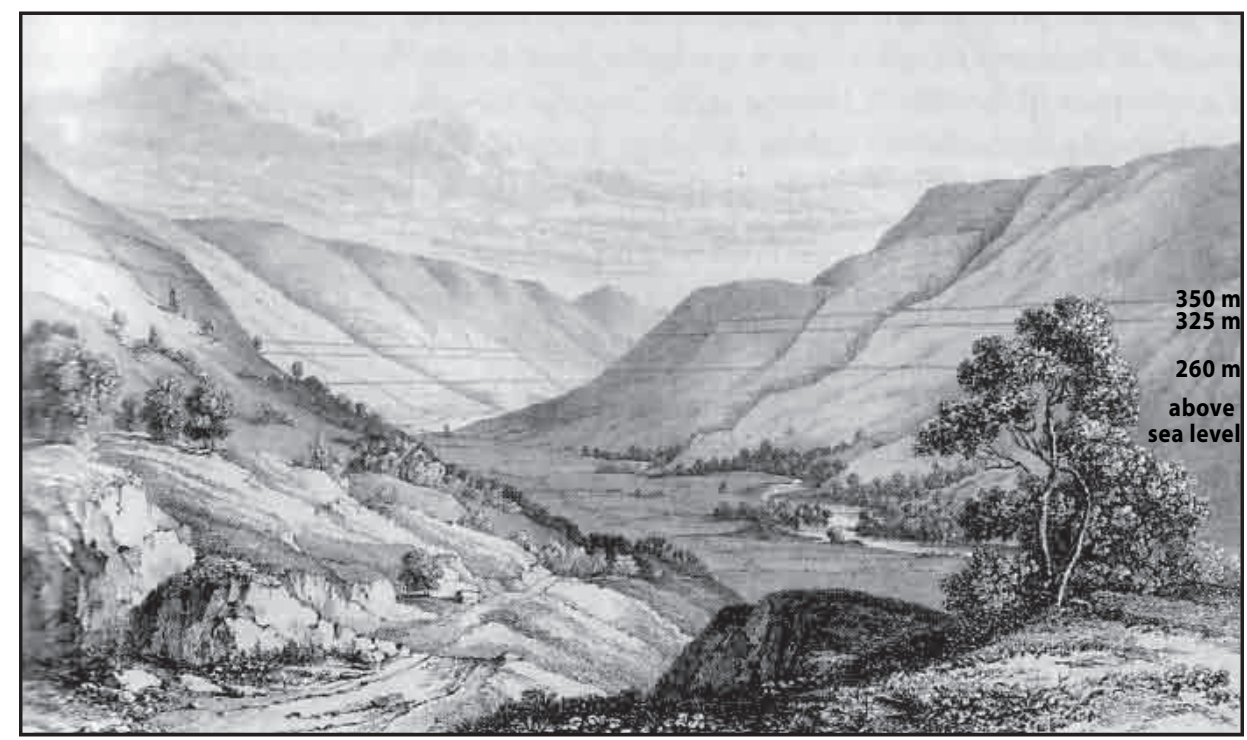

Figure 9. The Parallel Roads of Glen Roy (MacCulloch 1817), three horizontal terraces in Lochaber between 260 and $350 \mathrm{~m}$ above sea level, as viewed from the mouth of the glen (Fig. 10).

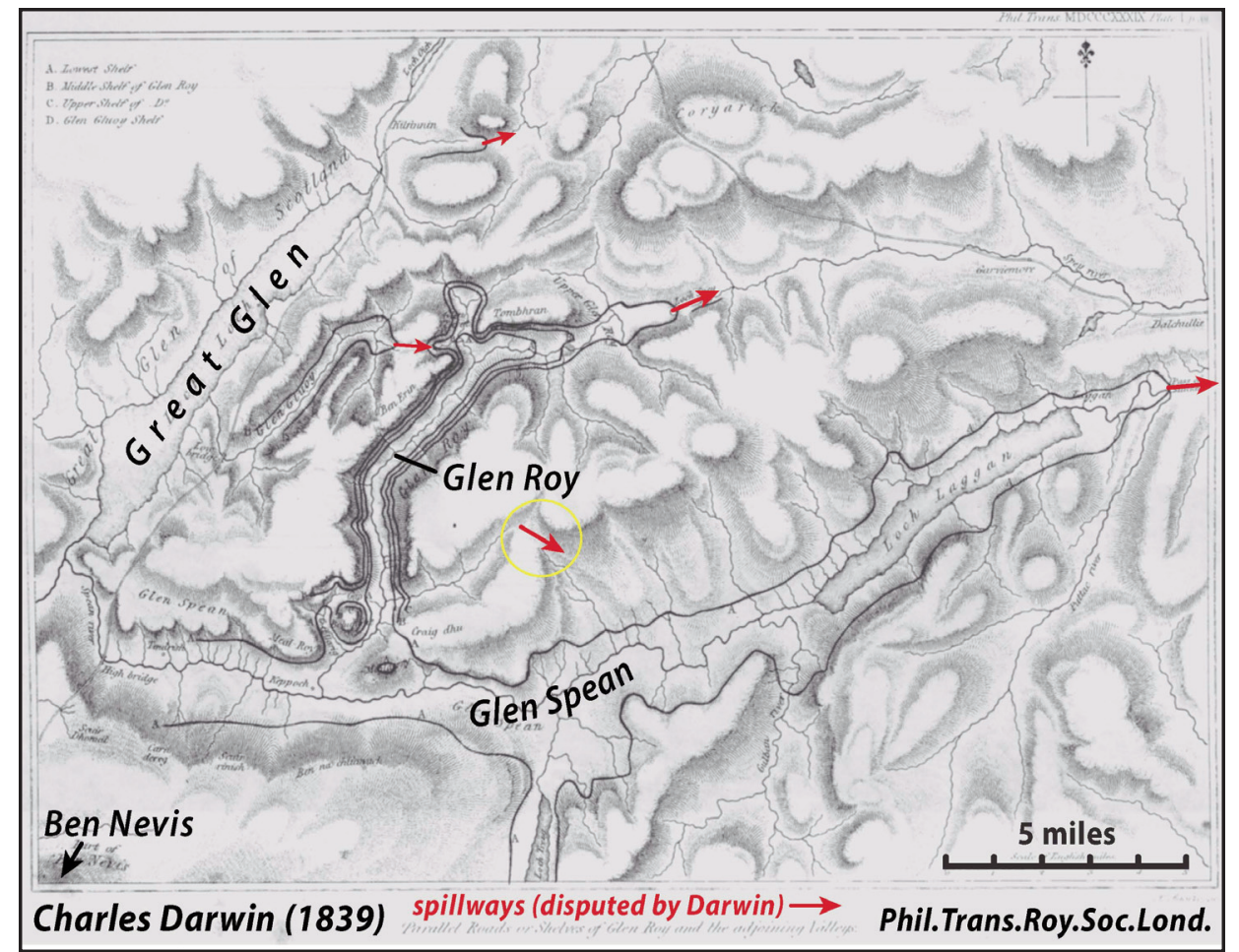

Figure 10. Charles Darwin's map of the terraces in and around Glen Spean and Glen Roy map (Darwin 1839b), with spillways (red arrows) supporting a lacustrine origin for the terraces added. However, no dam at the mouth of the glen exists. Note that only the lowest terrace occurs in Glen Spean. Darwin, who alone argued for a marine origin for the terraces, claimed that no spillway exists for the middle terrace. It exists at the head of the first tributary of Glen Roy (yellow circle), which Darwin did not map. Agassiz, visiting with Buckland in 1840, realized from his experience in the Alps (Fig. 11) that the lake in Glen Roy had been dammed by glacial ice in Glen Spean, and the subsequent lake in both glens by ice in the Great Glen (Agassiz 1840c, 1842). 


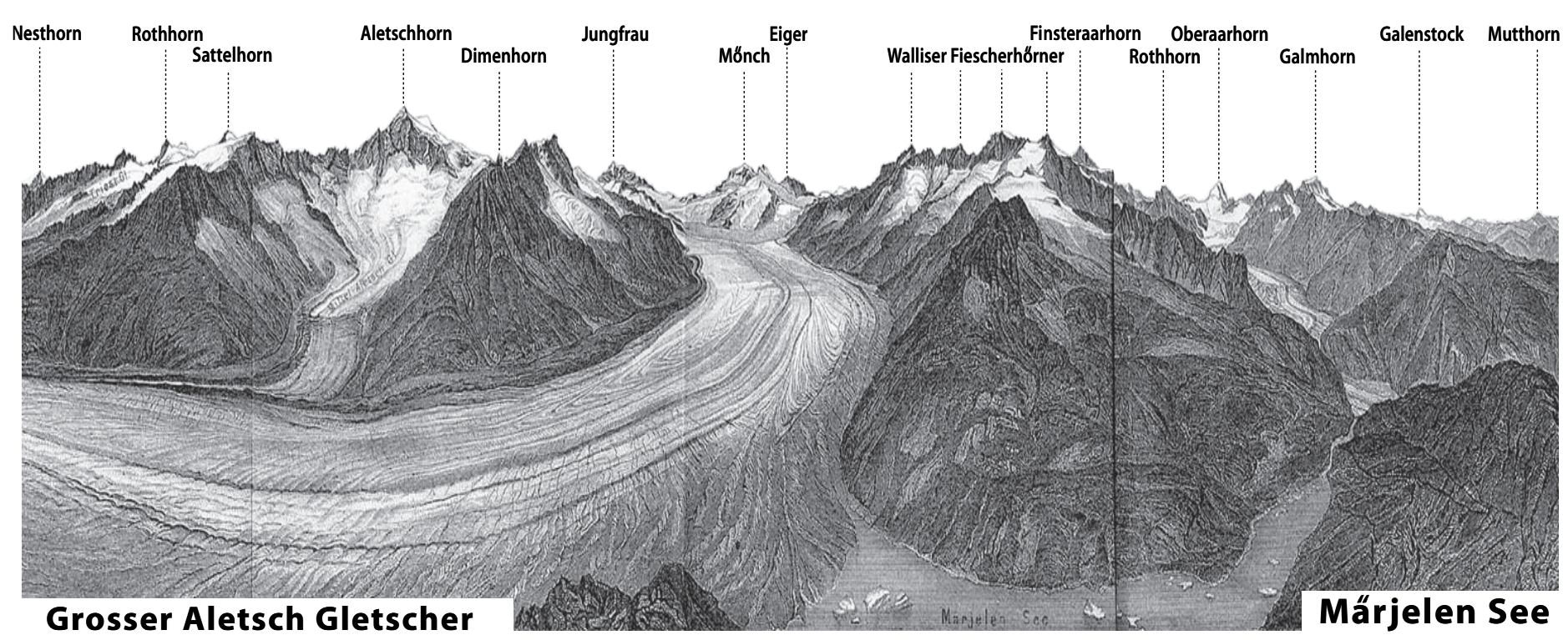

Figure 11. Aletsch Glacier and the ice-dammed Märjelen See (Lake), lower right, in Canton Valais (upper Rhône basin), Switzerland, as seen in 1900. The lake, deemed a flood hazard, was later drained. Engraving courtesy of Michel Azéma.

back-to-back papers applying the glacial theory in the British Isles at the Geological Society of London in November 1840 (Agassiz 1840c, 1841; Buckland 1840; Lyell 1840b)_Lyell's, in my opinion, is the most tightlyargued paper of the three. In question period, the glacial theory was condemned as unscientific by the Society establishment, notably Conybeare, Murchison and William Whewell (1794-1866). Against strict Society regulations, the question period was transcribed, and later published (Woodward 1882, 1907; Herries Davies 2007). The news of Agassiz and Buckland's tour of the Grampians (Bailey 1962; White 1970) and the image of glaciers in Britain caught on with the media and the public, never helpful for an aspiring scientific theory.

Early in the new year, Lyell reverted to his former stand against the glacial theory in his greatly expanded treatment of the topic (Fig. 7) in the 1841 second edition of Elements of Geology (Lyell 1841). In May, he formally requested that the full text of his Geological Society paper supporting the glacial theory be withdrawn (Boylan 1998; Herries Davies 2007). Lyell was not alone. Buckland had intended to revise his Reliquiae Diluvianae in light of the glacial hypothesis, but he got cold feet. For all his innovations, Buckland was a peace-maker at heart (Buckland 1841; see also Rupke 1983). Soon, he would begin to experience symp- toms of an illness (dementia?) that would shorten his productive career.

Interest in the glacial theory and support for it fell off precipitously after 1842, not only in Britain (Fig. 7). Historians have not critically analyzed why this happened. To its critics, the glacial theory (shed of its biological accoutrements, which Agassiz sensibly cast adrift) labored under three major difficulties. First, Lyell and most other geologists associated glaciers with mountains. There were no mountains in Britain in the Newer Pliocene, only a cluster of islets. Lyell's disbelief only increased in New England, the first leg of his Travels in North America, 1841-2 (Lyell 1845). If the glacial theory were true, the ice divide in New England should have coincided with the highest range of the northern Appalachians, the Green Mountains. Instead, Lyell learned from Edward Hitchcock (1793-1864) that the drift of New England came from north of the St Lawrence River. It had flowed obliquely across the Green Mountains as if the range did not even exist (Hitchock 1841a, b). Neither Lyell nor Hitchcock sufficiently understood that an ice sheet flows under its own weight: "all that was needed was a general southward slope in the upper surface of the glacier, or simply a greater accumulation of ice to the north than to the south" (Dana 1880, p. 535).

The second problem was the submergence itself. It was best framed by Charles Maclaren (1782-1866), founding editor of The Scotsman, Scotland's first independent Liberal newspaper. In his astute review of Études sur les glaciers (Maclaren 1842), he noted that the melting of the mass of glacial ice envisaged by Agassiz should have raised sea level by over $200 \mathrm{~m}$ on average globally (Agassiz erroneously assumed that an ice sheet existed over northern Asia, as well as northern Europe and North America). In reality, sea level stood higher, not lower, in Britain and Scandinavia during the drift period. The glacial theory appeared to contradict evidence from marine fossils that all geologists knew and accepted as true. It would be decades, long after the glacial theory had been accepted (Fig. 7), before the actual causes of iceage submergence were correctly identified as the loading of the land by ice masses, aka glacial isostasy (Shaler 1874; Jamieson 1882), and the gravitational attraction between the ice masses and seawater, aka ice gravity (Jamieson 1882; Penck 1882). The answer to the old question about the land sinking or the sea rising would be, both. Combined, they had easily outstripped the glacioeustatic response that Maclaren (1842) had deduced. The third problem for the glacial theory was Agassiz's extreme depiction of ice-age Britain. Former glaciers in northern Britain resembling those found today in the Alps and Norway would perhaps have been acceptable to British geologists, but 
this is not what Agassiz offered them. Virtually all of Britain had been covered by a continuous ice sheet, Agassiz insisted, "like Greenland" (Agassiz 1840c, 1842). Only the tops of the highest peaks emerged above the surface of the ice sheet, which filled every valley. Why was Agassiz so insistent on this point, insistent to the detriment of his own theory? Agassiz had puzzled over the fact that Swiss moraines carry two types of pebbles and boulders, those that are smooth, rounded and polished, and those that are unpolished and angular. After close examination of active glaciers, Agassiz realized that the rounded clasts were carried along at the base of the glacier, in the "couche de bou" (bed of muck) that forms a bed on which the glacier slides. Their roundness and polish is due to trituration, or milling by rock paste. As James David Forbes would explain, "It is not the wheel of the lapidary which slits a pebble, but the emery with which it is primed. The gravel, sand, and impalpable mud are the emery of the glacier" (Forbes 1843, p. 47). Angular clasts, in contrast, originate when landslides on mountain slopes above a glacier drop debris into the top of the ice, which dutifully carries it passively to the ablation zone, where it is gently lowered onto the subglacial bed (ground moraine) as the ice disappears. In the Scottish tills, Agassiz had found rounded and polished clasts only, no angular debris. He had inferred from this observation that nunataks were inconsequential in iceage Britain; the country had been almost completely buried by ice (Agassiz 1840c, 1842). This was a remarkably astute inference on which to base such a bold conjecture. In retrospect, we know the inference was substantially correct (Boulton and Hagdorn 2006), but the reasoning was too subtle for geologists like Lyell, who had never been close to an active glacier. One geologist who had (Herbert 1999) would write a moving description of trimlines marking the former surface of the British Isles ice nappe in the mountains of North Wales (Darwin 1842b). But thereafter, Darwin also, would turn against the glacial theory (Darwin 1848, 1855).

James Smith returned to the Mediterranean after the 1840 Glasgow meeting, but as local co-chair he had made a small decision that would have lasting consequences for the glacial theory. He apparently appointed a young local amateur to a committee charged with constructing a scalemodel and map of the geology on the Isle of Arran (Firth of Clyde) for display at the meeting in advance of a field excursion. Andrew (later Sir Andrew) Crombie Ramsay (1814-1891) took charge of the project, on the strength of which he was offered an assistant geologist position with the British Geological Survey (McCallien 1941). Along with Robert Chambers (1802-1871), Ramsay kept the glacial theory alive during the period of rejection (Fig. 7) with his field work in North Wales (Ramsay 1852, 1866) and his finely-crafted handbooks aimed at the emergent middle class (Ramsay 1860, 1864). He championed the glacial origin of Lake Geneva and other overdeepened lake basins (Ramsay 1862; see also Herries Davies 1969), and was the godfather of a group of young Scottish geologists (Fig. 12), whose systematic studies led, unexpectedly, to the general and permanent acceptance of the glacialnappe theory in 1860-65 (Fig. 7).

Simultaneously, the Irish-English physicist and mountaineer John Tyndall (1820-1893) conducted experiments with pure gases demonstrating that tri-atomic and larger molecules $\left(\mathrm{H}_{2} \mathrm{O}_{\mathrm{v}}, \mathrm{CO}_{2}, \mathrm{C}_{2} \mathrm{H}_{4}\right)$ absorb in the infrared part of the spectrum but are transparent to sunlight (Tyndall 1861, 1863). Water vapour, wrote Tyndall (1863), "is a blanket more necessary to the vegetable life of England than clothing is to man. Remove for a single summer-night the aqueous vapour from the air which overspreads this country, and you would assuredly destroy every plant capable of being destroyed by a freezing temperature. The warmth of our fields and gardens would pour itself unrequited into space, and the sun would rise upon an island beld fast in the iron grip of frost. The aqueous vapour constitutes a local dam, by which the temperature at the earth's surface is deepened: the dam, however, finally overflows, and we give to space all that we receive from the sun." Tyndall knew, however, that the water vapour content of the atmosphere will not rise unless the atmosphere is first warmed. Although water vapour is a powerful amplifier of climate change, it cannot be a driver of change on a
Quaternary time scale because its concentration is a strict function of temperature itself. On the other hand, Tyndall thought that the concentrations of $\mathrm{CO}_{2}$ and the hydrocarbon gases could conceivably change independent of temperature. He marvelled that small changes in these variable yet trace constituents of the atmosphere "may have produced all the mutations of climate which the researches of geologists reveal" (Tyndall 1861). However, radiative transfer in the real atmosphere cannot be captured by experiments with pure gases, or with measurements having low spectral resolution. Questions were raised (Ångström 1900; see also Archer and Pierrehumbert 2011). Does water vapour absorb all the radiation that $\mathrm{CO}_{2}$ would even if $\mathrm{CO}_{2}$ were absent? Does $\mathrm{CO}_{2}$ absorb all the energy it can already, so that raising its concentration would have no additional impact on surface temperature? These and other questions could not be answered without knowledge of the composition and thermal structure of the upper troposphere, where Earth's long-wavelength emissions can actually escape to space, and where Fourier's radiative balance is actually established and maintained. It would be over 100 years before it was properly understood how changes in the concentration of $\mathrm{CO}_{2}$ and other 'greenhouse' gases in the atmosphere cause changes in Earth's surface temperatures (Manabe and Wetherald 1967).

During the years 1841-46, while his family resided on Gibraltar and Malta, James Smith geologized on the islands and other parts of the Mediterranean, as he had on Madeira (Smith 1841, 1862b). But as his familiarity with the inland sea grew, his ardor was increasingly drawn to its human history. As a sailor and scholar, he thought he might contribute to a longstanding controversy over the author and veracity of the voyage and shipwreck of St. Paul in late $59 \mathrm{AD}$, as narrated in the Acts of the Apostles (27-28) in the New Testament. The Biblical critical movement in Protestant central Europe in the mid- $18^{\text {th }}$ Century had laid bare many contradictions between the earliest known sources of New Testament Scripture. The movement's wide influence in opposition to religious fundamentalism was reflected in 


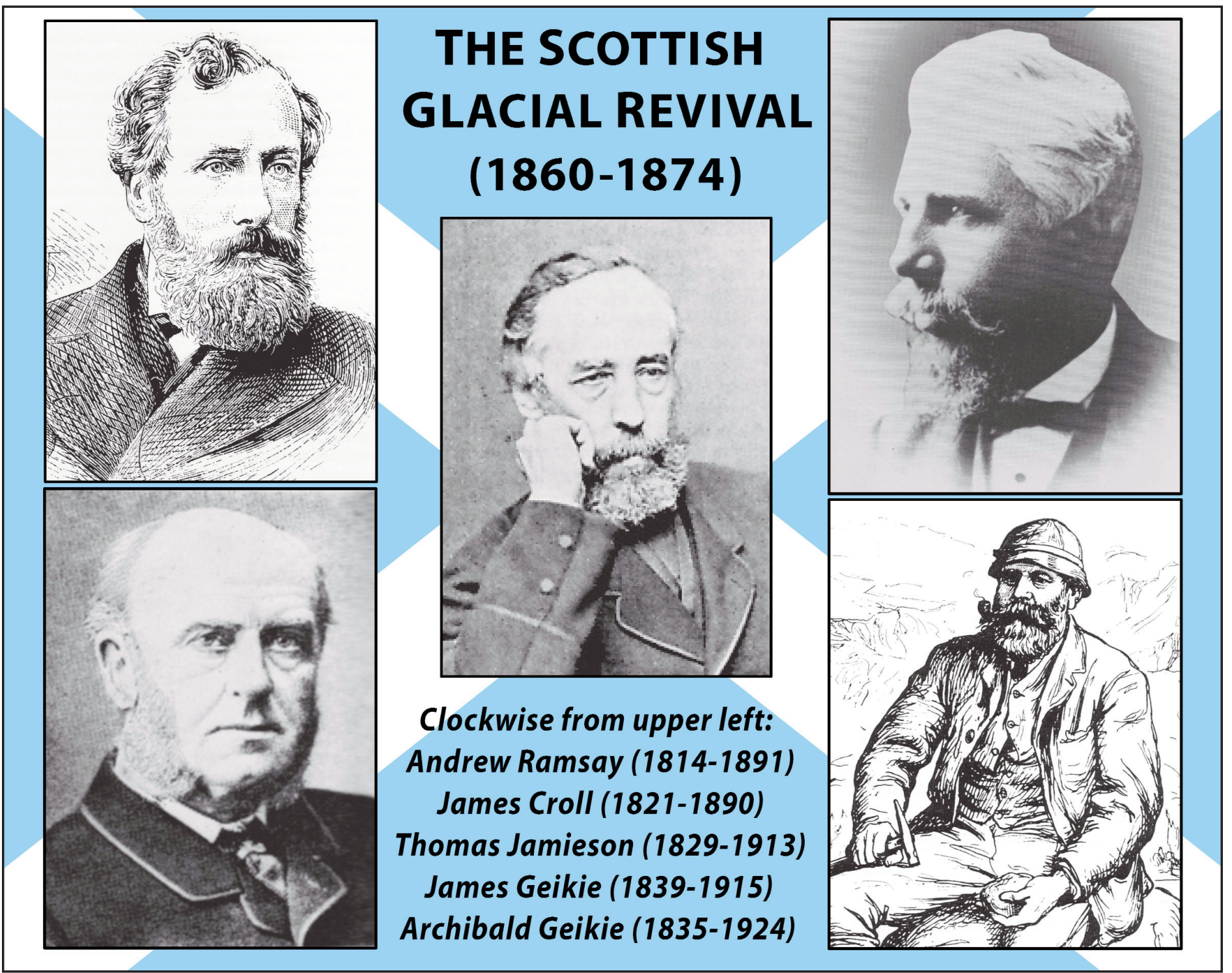

Figure 12. The Scottish glacial revival, geological contemporaries whose work led to the general acceptance of the glacial-nappe theory after the early 1860's (Fig. 7). Clockwise from upper left: Andrew C. Ramsay (1814-1891), who confirmed (after Darwin 1842b) that an ice sheet formerly existed over North Wales and postulated a glacial origin for Lake Geneva and other deep 'finger' lakes (Ramsay 1860, 1862, 1866); James Croll (1821-1890), who developed the first orbital theory for glacial-interglacial cycles and the concept of snow(ice)-albedo feedback, and wrote the first treatise on paleoclimate (Croll 1864, 1875); Thomas F. Jamieson (1829-1913), who first attributed ice-age submergence to loading by ice (glacial isostasy) combined with ice gravity, and identified glacial forebulges and their collapse (Jamieson 1865, 1882); James Geikie (1839-1915), who recognized the Holocenelike character of Pleistocene interglacials and wrote the first major treatises on Ice Age geology (Geikie 1872, 1874, 1881, 1892); and Archibald Geikie (1835-1924), whose regional studies along with those of Jamieson (1865) established the glacial-nappe theory in Scotland and, as a prolific and lucid writer, captured the public imagination by linking the glacial theory to the scenery of Scotland (Geikie 1863, 1865, 1887, 1892). Of Croll (1875), a reviewer in Nature remarked, "Mr. Croll does not possess the happy faculty which some authors have of carrying their readers with them: in the contrary, his style is so controversial, that to agree with him is to have the feeling of being vanquished, and the reader is throughout set on bis metal to find out some flaw in the argument."

the strong secularism (separation of church and state) of the founding fathers of the United States, progressive even by modern (American) standards. In Britain, fears over a loss of faith among the population led an ageing William Paley (1743-1805) to craft his heartfelt and beautifully-written
Natural Theology (Paley 1802), with its famous metaphor of the natural world as a finely-crafted pocket watch. Intelligent design, an idea older than history, was the self-evident explanation for what all naturalists observed: species are exquisitely well-adapted to their natural environments. The book Natu- ral Theology is an exposition on adaptation in nature, upon which the teleological argument is presented "not as a chain of reasoning like Euclid's, where one weak link would spoil the whole argument. It is instead a rope, where the various fibres are in themselves weak, but twisted together will support a great weight" (Eddy and Knight 
2006). Accepted by virtually every natural philosopher of the early $19^{\text {th }}$ Century, including the young Charles Darwin, intelligent design was an inference that the theory of natural selection would render unnecessary.

In 1842, with natural selection existing only as a pencil-written sketch in Darwin's files (Darwin and Wallace 1958), Smith faced many uncertainties regarding the voyage and shipwreck of St. Paul, which, according to local legend, ended at St. Paul's Bay on the island of Malta (Melita). Did the voyage actually occur as described in the New Testament (Acts 27-28)? Was Malta the site of the shipwreck? Was St. Luke the anonymous narrator as traditionally assumed, but recently questioned? Was his account that of an eyewitness to the events, or the piecemeal report of a correspondent? Ships of the day had canoe-shaped hulls with V-sterns, as seen on Roman coins which, to show the strength of the currency, were often embossed with symbols of trade (ships) and war (ships). With his intimate knowledge of sailing and of the ships and navigation techniques of the ancients, as well as his access to library collections in Europe and the Near East, Smith hoped to shed light on these issues, not as a pious man (which he assuredly was), but "precisely as I would any antient voyage of doubtful authority" (Smith 1848). In particular, he aimed to resolve the identity of the narrator and, if it was St. Luke, to evaluate his reliability as a witness to events.

According to Acts, St. Paul was jailed during his third and last visit to Jerusalem in $57 \mathrm{AD}$, charged with proselytizing against Jewish beliefs and customs. He was held in captivity for two years in Caesarea, then the Roman administrative capital of the province of Judea and situated on the Mediterranean coast between Tel Aviv and Haifa in modern Israel. With the arrival of a new Governor in late 59 AD, St. Paul's request to have his case heard before the Roman Emperor Nero (54-68 AD) was granted. Although late in the season, St. Paul and a number of other prisoners and their guard detail embarked on a trading ship bound for Rome via the south coast of Asia Minor (Turkey) and Crete. After leaving Crete, the ship was struck in the Ionian Sea by a severe winter storm with northeasterly gales. After missing Sicily to the south, the ship reportedly ran aground and was destroyed on Malta, but all hands were saved and St. Paul eventually reached Rome in $60 \mathrm{AD}$ (where he waited another two years for his hearing before the Emperor, the outcome of which remains uncertain but probably did not end well for the accused). James Smith, after comparing all the known early transcriptions of the story line-by-line, and after reconstructing the entire voyage in light of the seasonal weather patterns of the region, and the sailing and navigation practices of the time, concluded that the most telling evidence is the style of the narrative itself. Luke had some maritime experience, unlike other proposed narrators, and was therefore casually familiar with the lexicon of sailors. But he was not a sailor and therefore did not recognize as anomalous, procedures followed under unusual circumstances. The narrator of Acts reports many nautical actions taken, from which no explanatory meaning is drawn, nor any rhetorical purpose served (McGrew, undated). To cite only the most dramatic examples, on the night of the shipwreck, they were being driven downwind when, forewarned by soundings, they heard breakers in the darkness dead ahead. The narrator describes what happened next, "Then fearing lest we should have fallen upon rocks, they [the sailors] cast four anchors out of the stern, and wished for the day [light]" (Acts 27, verse 29). No hint is given why this unusual action (casting anchors from the stern) was taken: it was to prevent the ship turning broadside into the wind and striking rocks leeward, and to have the bow pointed shoreward in preparation for beaching at daybreak. After securing anchorage, "they lightened the ship, and cast out the wheat [cargo and provisions] into the sea" (Acts 27, verse 38). Again, no explanation is given why they took this precaution when they did, after not doing so during the height of the storm at sea. It was to run the ship aground as high as possible on the beach, which they did. "No sailor would have written in a style so little like that of a sailor; no man not a sailor could have written a narrative of a sea voyage so consistent in all

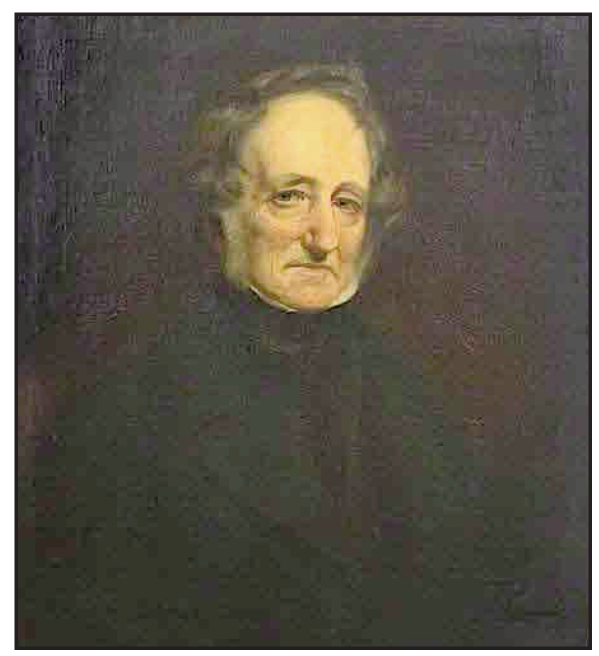

Figure 13. James Smith, age 71, as Provost of the Burgh of Helensburgh. Oil painting attributed to James Wilson. Argyll and Bute Council.

its parts, unless from actual observation. This peculiarity of style is to me, in itself, a demonstration that the narrative of the voyage is an account of real events, written by an eyewitness." (Smith 1848, p. xix).

After returning to Jordanhill in 1846, and despite the loss of his wife of 38 years Mary Wilson Smith, James Smith (Fig. 13) published The Voyage and Shipwreck of St. Paul in 1848 to critical acclaim. As a testament to the reliability of St. Luke as an eyewitness, the book was unique. It went through four editions, the second significantly enlarged and the last issued posthumously in 1880. He published a second book of Biblical scholarship in 1853, in response to newly discovered texts, an enthusiasm for which he never lost (MacLehose 1886). He resumed his research on the tills of the Clyde (Smith 1846, 1850, 1862a) and collected all of his papers on Newer Pliocene geology together in one hardbound volume (Smith 1862b) with commentary and colour illustrations. He continued to sail and dredge for seashells until the age of 84 , and died one year later in 1867 with 'unimpaired faculties and many of his family around him.' He was, at the time, President of the eight-year-old Geological Society of Glasgow (Macnair and Mort 1908).

\section{REFERENCES}

Agassiz, L., 1837, Discours prononcé à l'ouverture des séances de la Société Helvétique des Sciences Naturelles, à Neuchâtel, le 24 juil- 
let 1837: Actes de la Société Helvétique des Sciences Naturelles, 22ème session, Neuchâtel, 24-26 juillet 1837, p. 5-32 (English translation in 1838 as Upon glaciers, moraines, and erratic blocks: Edinburgh New Philosophical Journal, v. 24, p. 364-383).

Agassiz, L., 1838-39, Observations sur les glaciers: Bulletin de la Société Géologique de France ( $1^{\text {st }}$ series), v. 9, p. 443-450 (English translation in 1839 as Remarks on glaciers: Edinburgh New Philosophical Journal, v. 27, p. 383-390).

Agassiz, L., 1840a, Études sur les glaciers: Jent \& Gassmann, Neuchâtel (English facsimile translation by A.V. Carozzi in 1967 as Studies on Glaciers, Preceded by the Discourse of Neuchâtel, 1837: Hafner, New York, 213 p., 18 plates)

Agassiz, L., 1840b, Glaciers and boulders in Switzerland (paper read at the British Association for the Advancement of Science, Glasgow, 22 Sept. 1840, with discussions by Lyell, Mallet, de la Beche, Murchison, Smith, Forbes, etc.): The Athenæum, v. 677, p. 824.

Agassiz, L., 1840c, Glaciers, and the evidence of their having once existed in Scotland, Ireland, and England (paper read at the Geological Society, London, Nov. 4, 1840): The Athenaeum, v. 682, p. 927-928 (reprinted in Philosophical Magazine ( $2^{\text {nd }}$ series), v. $18, p$. 569-574, 1841).

Agassiz, L., 1841, On the polished and striated surfaces of the rocks which form the beds of glaciers in the Alps: Philosophical Magazine ( $2^{\text {nd }}$ series), v. 18, p. 565-566.

Agassiz, L., 1842, The glacier theory and its recent progress: Edinburgh New Philosophical Journal, v. 33, p. 217-283.

Andersen, B.G., 1992, Jens Esmark - a pioneer in glacial geology: Boreas, v. 21, p. 97-102, http://dx.doi.org/ 10.1111/j.1502-3885.1992.tb00016.x.

Ångström, K., 1900, Über die Bedeutung des Wasserdampfes und der Koblensäure bei der Absorbtion der Erdatmosphäre: Annalen der Physik, v. 308, p. 720-732, http://dx.doi.org/10.1002/andp.1900 3081208.

Anonymous, 1924, Clyde yachting - Royal Northern Centenary - early club history, part 1: The Glasgow Herald, v. 142, no. 31, p. 3.

Archer, D., and Pierrehumbert, R., eds., 2011, The Warming Papers: The scientific foundation for the climate change forecast: Wiley-Blackwell, Oxford, 419 p.

Bailey, E.B., 1962, Charles Lyell (British
Men of Science): Thomas Nelson and Sons, London, 214 p.

Barrett, P.H., 1973, Darwin's 'gigantic blunder': Journal of Geological Education, v. 21, p. 19-28.

Bernhardi, A., 1832, Wie kamen die aus dem Norden stammenden Felsbruchstücke und Geshiebe, welche man in Norddeutschland und den benachbarten Ländern findet, an ibre gegenwärtigen Fundorte? (How did the rock fragments and boulders of northern origin found in northern Germany and neighboring countries get to their present positions?): Jahrbuch für Mineralogie, Geognosie, Geologie, und Petrefaktenkunde, v. 3, p. 257-267.

Boucher de Perthes, J., 1857, Antiquités celtiques et antédiluviennes: Mémoire sur l'industrie primitive et les arts à leur origine (vol. 2): Treuttel and Wurtz, Paris.

Boulton, G., and Hagdorn, M., 2006, Glaciology of the British Isles Ice Sheet during the last glacial cycle: form, flow, streams and lobes: Quaternary Science Reviews, v. 25, p. 3359-3390, http://dx.doi.org/ 10.1016/j.quascirev.2006.10.013.

Boylan, P.J., 1998, Lyell and the dilemma of Quaternary glaciation, in Blundell, D.J., and Scott, A.C., eds., Lyell: The Past is the Key to the Present: Geological Society of London, Special Publications, 143 , p. 145-159, http://dx.doi.org/10.1144/GSL.SP.19 98.143.01.13.

Bravais, A., 1840, Sur les lignes d'ancien niveau de la mer dans le Finnmark: Compte Rendu Academie des Sciences de Paris, v. 10, p. 691-708 (republished in English in 1845 as, On the lines of ancient sea level of the Sea in Finnmark: Quarterly Journal of the Geological Society of London, v. 1, p. 534-549).

Brongniart, A., 1828, Notice sur les blocs de roches des terrains de transport en Suède: Annales des Sciences Naturelles (ser. 1), v. 14, p. 1-22.

Bruce, F.F., 1959, The New Testament Documents: Are They Reliable? $4^{\text {th }}$ ed.: Wm B. Eerdman's, Grand Rapids, Michigan, $135 \mathrm{p}$.

Buch, L., von, 1810, Riese durch Norwegen und Lappland: J. S. Nauck, Berlin, v. 1, 486 p.; v. 2, 406 p.

Buch, L., von, 1817, Sur les causes auxquelles on peut attribuer le transport des blocs de roches des Alpes, qui sont épars sur le Jura: Annales de chimie et de physique (Paris), v. 7, p. 17-32.

Buch, L., von, 1819, Additions au mémoire sur les causes du transport des bloc de roches des Alpes sur le Jura: Annales de chimie et de physique (Paris), v. 10, p. 241-264.

Buckland, W., 1820, Vindiciae Geologicae, or the connexion of Geology with Religion explained, in an Inaugural Lecture delivered before the University of Oxford, May 15, 1819, on the Endowment of a Readership in Geology by His Royal Highness the Prince Regent: Oxford University Press, Oxford, 38 p.

Buckland, W., 1821, Description of the Quartz Rock of the Lickey Hill in Worcestershire, and of the Strata immediately surrounding it; with considerations on the evidences of a Recent Deluge afforded by the gravel beds of Warwickshire and Oxfordshire, and the valley of the Thames from Oxford downwards to London; and an Appendix, containing analogous proofs of diluvian action. Collected from various authorities: Transactions of the Geological Society of London, v. 5, p. 506-544.

Buckland, W., 1822a, On the excavation of valleys by diluvial action, as illustrated by a succession of Valleys which intersect the South Coast of Dorsetshire and Devonshire: Transactions of the Geological Society of London, 2nd ser., v. 1, p. 95-102.

Buckland, W., 1822b, Account of an assemblage of fossil teeth and bones of elephant, rhinoceros, hippopotamus, bear, tiger, and hyæna, and sixteen other animals, discovered in a cave at Kirkdale, Yorkshire, in the year 1821: with a comparative view of five similar caverns in various parts of England, and others on the Continent: Philosophical Transactions of the Royal Society, London, v. 112, p. 171-236, http:/ /dx.doi.org/ 10.1098/rstl.1822.0017.

Buckland, W., 1823, Reliquiae Diluvianae; or, observations on the organic remains contained in caves, fissures, and diluvial gravel, and on other geological phenomena, attesting the action of an universal deluge: John Murray, London, 303 p. (reprinted in 2011 by Cambridge University Press, New York).

Buckland, W., 1836, Geology and Mineralogy Considered with Reference to Natural Theology (2 vol.): W. Pickering, London, 474 p. (reprinted in 1980 by Arno Press, New York).

Buckland, W., 1840, On the former existence of glaciers in Britain: Edinburgh New Philosophical Journal, v. 30, p. 194-198, 202-205 (reprinted in Philosophical Magazine ( $2^{\text {nd }}$ series), v. 18, p. 574-579, 1841). 
Buckland, W., 1841. Anniversary address of the President, 19 Feb. 1841. Proceedings of the Geological Society of London, v. 3, p. 469-540.

Carozzi, A.V., 1966, Agassiz's amazing geological speculation: the Ice-Age: Studies in Romanticism, v. 5, p. 57-83, http://dx.doi.org/10.2307/25599657.

Celsius, A., 1743, Anmärkning om vatnets för minskande så i östersiön som vesterhalvet: Kongliga Swenska Wetensskaps Academiens Handlingar, v. 4 , p. $33-50$.

Chambers, R., 1848, Ancient sea margins as memorials of changes in the relative level of the sea and land: W.S. Orr, London, 335 p.

Charpentier, J. de, 1835, Notice sur la cause probable du transport des blocs erratiques de la Suisse: Annales des Mines, $3^{\text {rd }}$ Series, v. 8, p. 219-236.

Charpentier, J. de, 1836, Account of one of the most important results of the investigations of M. Venetz, regarding the present and earlier conditions of the glaciers of the Canton Vallais: Edinburgh New Philosophical Journal, v. 21, p. 210-220 [translation of Annonce d'un des principaux résultats des recherches de $M$. Venetz, ingénieur des ponts et chaussées de canton du Valais, sur l'état actuel et passé des glaciers du Vallais: Actes de la Société Helvétiques des Sciences Naturelles (19ème session, Lucerne, 28-30 Juillet 1834), p. 23-24, 1835).

Charpentier, J. de, 1841, Essai sur les glaciers et sur le terrain erratique du Bassin du Rhône: Ducloux, Lausanne, 363 p.

Chorley, R.J., Dunn, A.J., and Beckinsale, R.P., 1964, The History of the Study of Landforms, or the Development of Geomorphology, Vol. 1: Geomorphology before Davis: Methuen, London, $678 \mathrm{p}$.

Conybeare, W.D., and Phillips, W., 1822, Outlines of the Geology of England and Wales, Part 1: William Phillips, London, 470 p. (reprinted in 1978 by Arno Press, New York).

Correa de Serra, J., 1799, On a submarine forest, on the East Coast of England: Transactions of the Royal Society of London, v. 89, p. 145-156, http://dx.doi.org/10.1098/rstl.1799.0 010.

Croll, J., 1864, On the physical cause of the changes of climate during geological epochs: Philosophical Magazine (series 4), v. 28, p. 121-137.

Croll, J., 1875, Climate and Time in their Geological Relations: a Theory of Secular Changes of the Earth's Climate: D. Appleton \& Co., New York, $577 \mathrm{p}$.

Cunningham, F.F., 1977, The Revolution in
Landscape: Tantalus, Vancouver, 136 p.

Cunningham, F.F., 1990, James David Forbes, pioneer Scottish glaciologist: Scottish Academic Press, Edinburgh, $329 \mathrm{p}$.

Dana, J.D., 1880, Dana's Manual of Geology, $3^{\text {rd }}$ ed.: Ivison, Blakeman, Taylor, and Co., New York, 911 p.

Darwin, C., 1837, Observations of proofs of recent elevation on the Coast of Chili, made during the survey of His Majesty's ship Beagle, commanded by Capt. Fitzroy, R.N.: Proceedings of the Geological Society of London, v. 2, p. 446-449.

Darwin, C., 1839a, Note on a rock seen on an iceberg in $61^{\circ}$ South Latitude: Journal of the Royal Geographical Society of London, v. 9, p. 528-529, http://dx.doi.org/10.2307/1797747.

Darwin, C., 1839b, Observations on the parallel roads of Glen Roy, and of other parts of Lochaber in Scotland, with an attempt to prove that they are of marine origin: Philosophical Transactions of the Royal Society, London, for 1839 , v. 139, p. 39-81, http://dx.doi.org/10.1098/rstl.1839.0 005.

Darwin, C., 1840, [Voyage of the Beagle] Journal of Researches into the Geology and Natural History of the Various Countries Visited by H.M.S. Beagle from 1832 to 1836: Henry Colburn, London, 637 p. (reprinted in 2009 by Cambridge University Press, New York).

Darwin, C., 1841, On the distribution of the erratic boulders and on the contemporaneous unstratified deposits of South America: Proceedings of the Geological Society of London, v. 3, p. 427-430.

Darwin, C., 1842a, The Structure and Distribution of Coral Reefs: 214 p., 3 plates (reprinted in 1984 by University of Arizona Press, Tucson).

Darwin, C., 1842b, Notes on the effects produced by the ancient glaciers of Caernarvonshire, and on the boulders transported by floating ice: Edinburgh New Philosophical Journal, v. 33, p. 352-363.

Darwin, C., 1848, On the transport of erratic boulders from a lower to a higher level: Quarterly Journal of the Geological Society, v. 4, p. 315-323, http://dx.doi.org/10.1144/GSL.JGS.1 848.004.01-02.44.

Darwin, C., 1855, On the power of icebergs to make rectilinear, uniformlydirected grooves accross a submarine undulatory surface: Philosophical Magazine, v. 10, p. 96-98.
Darwin, C., and Wallace, A.R., 1958, Evolution by Natural Selection: Darwin's sketch of 1842 , his essay of 1844 , and the Darwin-Wallace papers of 1858 On the Tendency of Species to Form Varieties, with an Introduction by Sir Francis Darwin and a Forward by Sir Gavin de Beer: Cambridge University Press, London, 288 p.

Davies, G.L., 1968, The tour of the British Isles made by Louis Agassiz in 1840: Annals of Science, v. 24, p. 131-146, http://dx.doi.org/10.1080/000337968 00200101.

Deshayes, G.-P., 1831, Tableau comparitif des espèces de coquilles fossiles des terrains tertiares de l'Europe, et des espèces de fossiles de ces terrains entr'eux: Bulletin de la Société Géologique de France (Paris), v. 1, p. 185-189.

Dick, T.L., 1823, On the parallel roads of Glen Roy: Transactions of the Royal Society of Edinburgh, v. 9, p. 1-64, 7 plates.

Eddy, M.D., and Knight, D., 2006, Introduction, in Paley, W., ed., Natural Theology: Oxford University Press, Oxford, p. ix-xxix.

Engelhardt, W. von, 1999, Did Goethe discover the ice age?: Eclogae geologicae Helveticae, v. 92, p. 123-128.

Esmark, J., 1824, Bidrag til vor jordklodes historie (Contribution to the geological history of our Earth): Magazin for Naturvidenskaberne, v. 2, p. 29-54.

Esmark, J., 1826, Remarks tending to explain [sic] the geological history of the Earth: Edinburgh New Philosophical Journal, v. 2, p. 107-121 (English translation of Esmark 1824).

Evans, E.P., 1887, The authorship of the glacial theory: The North American Review, v. 145, no. 368, p. 94-97.

Evenson, E.B., Burkhart, P.A., Gosse, J.C., Baker, G.S., Jackofsky, D., Meglioli, A., Dalziel, I., Kraus, S., Alley, R.B., and Berti, C., 2009, Enigmatic boulder trains, supraglacial rock avalanches, and the origin of "Darwin's boulders", Tierra del Fuego: GSA Today, v. 19, p. 4-10, http://dx.doi.org/ 10.1130/GSATG72A.1.

Farrand, W.R., 1990, Origins of Quaternary-Pleistocene-Holocene stratigraphic terminology, in Laporte, L.F., (ed.), Establishment of a Geologic Framework for Paleoanthropology: Geological Society of America, Special Papers, v. 242, p. 15-22, http://dx.doi.org/10.1130/SPE242p15.

Fleming, J., 1823, On a submarine forest in the Frith of Tay, with observations on the formation of submarine forests in general: Transactions of the Royal 
Society of Edinburgh, v. 9, p. 419-431, http://dx.doi.org/ 10.1017/S0080456800030994.

Fleming, J., 1824, Remarks illustrative of the influence of society on the distribution of British animals: Edinburgh Philosophical Journal, v. 11, p. 287-305.

Fleming, J.R., 1998, Charles Lyell and climate change: speculation and certainty, in Blundell, D.J., and Scott, A.C., eds., Lyell: the Past is the Key to the Present: Geological Society, London, Special Publications, 143, p. 161-169, http://dx.doi.org/10.1144/GSL.SP.19 98.143.01.14.

Forbes, E., 1846, On the connexion between the distribution of the existing fauna and flora of the British Isles, and the geological changes which have affected their area, especially during the epoch of the Northern Drift: Memoirs of the Geological Survey of Great Britain, v. 1, p. 336-403.

Forbes, J.D., 1842, The glacier theory (review of books by Venetz, Charpentier, Agassiz, le Chanoine and Necker): Edinburgh Review, v. 80, p. 49-105.

Forbes, J.D., 1843, Travels Through the Alps of Savoy, and Other Parts of the Pennine Range: Adam \& Charles Black, Edinburgh, 462 p.

Fourier, J., 1824, Remarques générales sur les températures du globe terrestre et des espaces planétaires: Annales de Chimie et de Physique (Paris), $2^{\text {nd }}$ series, v. 27, p. 136-167 (English translation by Ebenezer Burgess in 1837, General remarks on the temperature of the terrestrial globe and the planetary spaces: American Journal of Science and Arts, v. 32, v. p. 1-20.)

Fourier, J.-B.F., 1827, Mémore sur les températures du globe terrestre et des espaces planétaires: Mémoires de l'Académie Royale des Sciences (Paris), v. 7, p. 569-604 (English translation by Raymond T. Pierrehumbert in 2011, On the temperatures of the terrestrial sphere and interplanetary space, in Archer, D., and Pierrehumbert, R., eds., The Warming Papers: Wiley-Blackwell, Chichester, England, p. 7-20.

Geikie, A., 1863, On the phenomena of the glacial drift of Scotland: Transactions of the Geological Society of Glasgow, v. 1, no. 2, p. 1-190, http:/ /dx.doi.org/10.1144/transglas.1.2.1.

Geikie, A., 1865, The Scenery of Scotland, viewed in connexion with its physical geology: MacMillan \& Co., London, 360 p.

Geikie, A., 1887, The Scenery of Scotland, viewed in connexion with its physical geology, $2^{\text {nd }}$ ed.: MacMillan \& Co., London, $481 \mathrm{p}$.

Geikie, A., 1892, Geological Sketches, at home and abroad: MacMillan \& Co., New York, 332 p.

Geikie, J., 1872, On changes of climate during the glacial epoch: Geological Magazine, v. 8, p. 545-553; v. 9, p. 23-31, 61-69.

Geikie, J., 1874, The Great Ice Age, and its relation to the antiquity of man: $\mathrm{D}$. Appleton \& Co., New York, 545 p.

Geikie, J., 1881, Prehistoric Europe, a geological sketch: Edward Stanford, London, $592 \mathrm{p}$.

Geikie, J., 1892, The Great Ice Age, and its relation to the antiquity of man, $3^{\text {rd }}$ ed.: D. Appleton \& Co., New York, $850 \mathrm{p}$.

Grayson, D.K., 1983, The Establishment of Human Antiquity: Academic Press, New York, 262 p.

Hall, J., 1814, On the revolutions of the earth's surface: Transactions of the Royal Society of Edinburgh, v. 7, pt. 1, p. 139-211.

Hansen, B., 1970, The early history of glacial theory in British geology. Journal of Glaciology, v. 9, p. 135-141.

Harrison, S., 2004, The Pleistocene glaciations of Chile, in Ehlers, J., and Gibbard, P.L., eds., Quaternary Glaciations - Extent and Chronology, Part III: Elsevier, Amsterdam, p. 89-103.

Herbert, S., 1999, An 1830s view from outside Switzerland: Charles Darwin on the "Beryl Blue" glaciers of Tierra del Fuego: Eclogae geologicae Helveticae, v. 92, p. 339-346.

Herbert, S., 2005, Charles Darwin, Geologist: Cornell University Press, Ithaca, 485 p.

Herries Davies, G.L., 1969, The Earth in Decay: a history of British geomorphology 1578-1878: Macdonald \& Co., London, 390 p.

Herries Davies, G.L., 2007, Whatever is Under the Earth: The Geological Society of London, 1807 to 2007: The Geological Society, London, 378 p.

Herschel, J.F.W., 1830, The Study of Natural Philosophy: Longman \& Co., London, 372 p.

Hitchcock, E., 1841a, Final Report on the Geology of Massachusetts, Vol. I: J. S. \& C. Adams, Amherst, MA, 831 p. (Chapter 2. Diluvium, or Drift, p. 350-406; Postscript, p. 3a-11a).

Hitchcock, E., 1841b, First Anniversary Address before the Association of American Geologists, at their second annual meeting in Philadelphia, April 5, 1841: American Journal of Science, v. 41, p. $232-276$.
Hollin, J.T., and Schilling, D.H., 1981, Late Wisconsin-Weichselian mountain glaciers and small ice caps, in Denton, G.H., and Hughes, T.J., eds., The Last Great Ice Sheets: John Wiley \& Sons, New York, p. 179-206.

Holzhauser, H., Magny, M., and Zumbühl, H.J., 2005, Glacier and lake-level variations in west-central Europe over the last 3500 years: The Holocene, v. 15, p. 789-801, http://dx.doi.org/ 10.1191/0959683605hl853ra.

Hutton, J., 1795, Theory of the Earth, with Proofs and Illustrations, Vol. 2: Edinburgh (republished in 2007, IndyPublish, Boston, 228 p.).

Jamieson, T.F., 1863, On the parallel roads of Glen Roy, and their place in the history of the glacial period: Quarterly Journal of the Geological Society of London, v. 19, p. 235-259, http://dx.doi.org/10.1144/GSL.JGS.1 863.019.01-02.26.

Jamieson, T.J., 1865, On the history of the last geological changes in Scotland: Quarterly Journal of the Geological Society of London, v. 21, p. 161-204, http://dx.doi.org/10.1144/GSL.JGS.1 865.021.01-02.24.

Jamieson, T.F., 1882, On the cause of the depression and re-elevation of the land during the glacial period: Geological Magazine, v. 9, p. 400-407, 457-466, http:/ /dx.doi.org/ 10.1017/S0016756800172061.

Leslie, J., 1804, An Experimental Inquiry in the Nature and Propagation of Heat: J. Mawman, London, 562 p.

Linnæus, C., 1745, Carl Linnai öländska och gothländska resa: Stockholm and Uppsala, $344 \mathrm{p}$.

Livingston, C., 1906, The parallel roads of Lochaber with relation to an ice-cap: Transactions of the Geological Society of Glasgow, v. 12, p. 326-353, http://dx.doi.org/10.1144/transglas.12.3.326.

Lyell, C., 1830, The Principles of Geology, Vol 1: John Murray, London, 511 p. (reprinted in 1990 with an Introduction by M. J. S. Rudwick by University of Chicago Press).

Lyell, C., 1833, The Principles of Geology, Vol. 3: John Murray, London, 509 p. (reprinted in 1990 by University of Chicago Press).

Lyell, C., 1835, The Bakerian Lecture.-On the proofs of a gradual rise of the land in certain parts of Sweden: Philosophical Transactions of the Royal Society, London, v. 125, p. 1-38, http://dx.doi.org/10.1098/rstl.1835.0 002.

Lyell, C., 1836, Anniversary address of the President, February 19, 1836. Pro- 
ceedings of the Geological Society of London, v. 2, p. 357-390.

Lyell, C., 1838, Elements of Geology, $1^{\text {st }}$ ed.: John Murray, London, 570 p.

Lyell, C., 1840a, The Boulder Formation, or Drift, and associated freshwater deposits composing the mud cliffs of eastern Norfolk: Proceedings of the Geological Society, London, v. 3, p. 171-179.

Lyell, C., 1840b, On the geological evidence of the former existence of glaciers in Forfarshire: Edinburgh New Philosophical Journal, v. 30, p. 199-202 (reprinted in Philosophical Magazine ( $2^{\text {nd }}$ series $)$, v. 18, p. 579-591, 1841).

Lyell, C., 1841, Elements of Geology, $2^{\text {nd }}$ ed.: Hilliard, Gray, and Co., Boston, $437 \mathrm{p}$.

Lyell, C., 1845, Travels in North America, 1841-2, with geological observations on the United States, Canada, and Nova Scotia (2 vol.): Wiley \& Putnam, New York, 231 p. (reprinted in 1978 by Arno Press, New York).

Lyell, C., 1863, The Geological Evidences Antiquity of Man, $3^{\text {rd }}$ ed.: John Murray, London, 551 p.

Lyell, C., 1865, Elements of Geology, 6th ed.: John Murray, London, 794 p.

MacCulloch, J., 1817, On the parallel roads of Glen Roy: Transactions of the Geological Society of London, v. 4, p. 314-392, http://dx.doi.org/ 10.1144/transgsla.4.314.

Mackenzie, G.S., 1835, On the theory of the Parallel Roads of Glen Roy: Philosophical Magazine, v. 7, p. 433-436.

Maclaren, C., 1842, The glacier theory of Prof. Agassiz: American Journal of Science and Arts, v. 42, p. 346-365.

MacLehose, J., 1886, James Smith, in Memoirs and Portraits of 100 Glasgow Men: Glasgow Digital Library, Ebooks, http://gdl.cdlr.strath.ac.uk/ mlemen/mlemen083.htm

Macnair, P., and Mort, F., 1908, History of the Geological Society of Glasgow, 1858-1908, with biographical notices of prominent members: Geological Society of Glasgow, 303 p. (reprinted by BiblioLife, Charleston, South Carolina, USA).

Manabe, S., and Wetherald, R.T., 1967, Thermal equilibrium of the atmosphere with a given distribution of relative humidity: Journal of the Atmospheric Sciences, v. 24, p. 241-258, http://dx.doi.org/10.1175/1520 0469(1967)024<0241:TEOTAW>2.0. $\mathrm{CO} ; 2$.

McCallien, W.J., 1941, The birth of glacial geology: Nature, v. 147 , p. $316-318$ http://dx.doi.org/10.1038/147316a0.
McGrew, T., undated, The old man and the sea: Library of Historical Apologetics, http:/ / historicalapologetics.org/theold-man-and-the-sea/

Mound, J.E., and Mitrovica, J.X., 1998, True polar wander as a mechanism for second-order sea-level variations: Science, v. 279 , p. $534-537$, http://dx.doi.org/10.1126/science. 279.5350 .534 .

Murchison, R.I., 1836, The gravel and alluvia of South Wales and Siluria as distinguished from a northern drift covering Lancashire, Cheshire, North Salop and parts of Worcester and Gloucester: Proceedings of the Geological Society of London, v. 2, p. 230-336.

Murchison, R.I., 1839, The Silurian System (2 vol.): John Murray, London, 882 p.

Murchison, R.I., 1842a, On the glacial theory: Edinburgh New Philosophical Journal, v. 33, p. 124-140.

Murchison, R.I., 1842b, Anniversary address of the President, February 18: Proceedings of the Geological Society of London, v. 2, p. 637-687.

North, F.J., 1943, Centenary of the glacial theory: Proceedings of the Geologists' Association, v. 54, p. 1-28.

Page, L.E., 1969, Diluvialism and its critics in Great Britain in the early nineteenth century, in Schneer, C.J., ed., Toward a History of Geology: M.I.T. Press, Cambridge, MA, p.257-271.

Paley, W., 1802, Natural Theology or Evidence of the Existence and Attributes of the Deity, collected from the appearances of nature: reprinted in 2006 by Oxford University Press, New York, 342 p.

Peacock, J.D., 1970, Glacial geology of the Lochy-Spean area: Bulletin of the British Geological Survey, v. 31, p. 185-198.

Penck, A., 1882, Schwankungen des Meerespiegels (Sea-level change): Jahrbuch der Geographischen Gesellschaft zu München, v. 7, p. 1-170.

Playfair, J., 1802, Illustrations of the Huttonian Theory of the Earth: William Creech, Edinburgh, 528 p. (reprinted in 1956, Dover, New York).

Prestwich, J., 1860, On the occurrence of flint-implements, associated with the remains of extinct mammalia, in undisturbed beds of a late geological period: Proceedings of the Royal Society of London, v. 10, p. 50-59, http://dx.doi.org/10.1098/rspl.1859.0 019.

Prestwich, J., 1879, On the origin of the Parallel Roads of Lochaber and their bearing on other phenomena of the glacial period: Philosophical Transactions of the Royal Society, London, v. 170, p. 663-726, http://dx.doi.org/ 10.1098/rstl.1879.0077.

Ramsay, A.C., 1852, On the superficial accumulations and surface-markings of North Wales: Quarterly Journal of the Geological Society, v. 8, p. 371-376, http://dx.doi.org/ 10.1144/GSL.JGS.1852.008.01-02.35

Ramsay, A.C., 1860, The Old Glaciers of Switzerland and North Wales: Longman, Green, Longman and Roberts, London, 116 p.

Ramsay, A.C., 1862, On the glacial origin of certain lakes in Switzerland, the Black Forest, Great Britain, Sweden, North America, and elsewhere: Quarterly Journal of the Geological Society, London, v. 18, p. 185-205, http://dx.doi.org/10.1144/GSL.JGS.1 862.018.01-02.31.

Ramsay, A.C., 1864, The Physical Geology and Geography of Great Britain: Edward Stanford, London, $2^{\text {nd }}$ ed., 199 p.

Ramsay, A.C., 1866, The Geology of North Wales: Longman, Green, Reader, and Dyer, London, 381 p., 27 plates.

Razumovsky, G. Kirilovich, 1819, Coup d'oeil géognostiquesur le nord de l'Europe en générale, et particulièrement de la Russie..., $2^{\text {nd }}$ éd.: Berlin, $67 \mathrm{p}$.

Razumovsky, G. Kirilovich, 1829, Des gros blocs de roche que l'on trouve épars on accumulés sur le terrain de natures très-diverses: Annales des Sciences Naturelles (Paris), v.18, p. 133-147.

Rudwick, M.J.S., 1969, The glacial theory: History of Science, v. 8, p. 136-157.

Rudwick, M.J.S., 1974, Darwin and Glen Roy: A "great failure" in scientific method?: Studies in the History and Philosophy of Science Part A, v. 5, p. 97-185, http://dx.doi.org/ 10.1016/0039-3681(74)90024-7.

Rudwick, M.J.S., 1992, Scenes from Deep Time: Early Pictorial Representations of the Prehistoric World: University of Chicago Press, 280 p.

Rudwick, M.J.S., 2005, Bursting the Limits of Time: The reconstruction of geohistory in the Age of Revolution: University of Chicago Press, 708 p., http://dx.doi.org/10.7208/chicago/9780226731148.001.0001.

Rudwick, M.J.S., 2008, Worlds before Adam: The reconstruction of geohistory in the Age of Reform: University of Chicago Press, 614 p., http://dx.doi.org/10.7208/chicago/9780226731308.001.0001.

Rupke, N.A., 1983, The Great Chain of History: William Buckland and the English school of geology 
(1814-1849): Clarendon Press, Oxford, 322 p.

Ryan, B.W.F., and Pitman, W.C., 1998, Noah's Flood: The new scientific discoveries about the event that changed history: Simon \& Schuster, New York, 319 p.

Ryan, W.B.F., Pitman, W.C., III, Major, C.O., Shimkus, K., Moskalenko, V., Jones, G.A., Dmitrov, P., Gorür, N., Sakinç, M., and Yüce, H., 1997, An abrupt drowning of the Black Sea Shelf: Marine Geology, v. 138, p. 119-126, http://dx.doi.org/ 10.1016/S0025-3227(97)00007-8.

Sedgwick, A., 1825, On the origin of alluvial and diluvial formations: Annals of Philosophy, v. 9, p. 241-257 and v. 10, p. $18-37$.

Sedgwick, A., 1830, Anniversary address of the President: Proceedings of the Geological Society of London, v. 1, p. 187-212.

Sedowick, A., 1831, Anniversary address of the President: Proceedings of the Geological Society of London, v. 1, p. 313-317.

Sefström, N.G., 1838, Untersuchung über die auf den Felsen Scandinaviens in bestimmter Richtung vorkommenden Furchen und deren wabrsheinlicher Enstehung (Investigation of Scandinavian outcrops exhibiting oriented striations and their probable origin): Annalen der Physik, v. 43, p. 533-570 (including comment by von Buch, p. 567-570).

Shaler, N.S., 1874, Preliminary report on the recent changes of level on the coast of Maine: Memoirs of the Boston Society of Natural History, v. 2, p. 321-323, 335-340.

Sissons, J.B., 1979, Catastrophic lake drainage in Glen Spean and the Great Glen, Scotland: Journal of the Geological Society, v. 136 , p. 215-224, http://dx.doi.org/10.1144/gsigs.136.2. 0215.

Smith, J., 1836, On indications of changes in the relative levels of Sea and Land in the West of Scotland: Proceedings of the Geological Society, London, v. 2, p. 427-429 (reprinted in Smith 1862b).

Smith, J., 1837, On the changes which have taken place in the levels of Scotland: British Association for the Advancement of Science, Liverpool, v. 7, p. 87.

Smith, J., 1839a, On the climate of the Newer Pliocene Tertiary Period: Proceedings of the Geological Society of London, v. 3, p. 118-119 (reprinted in Smith 1862b).

Smith, J., 1839b, On the relative ages of the Tertiary and post-Tertiary deposits of the Basin of the Clyde: Proceed- ings of the Geological Society of London, v. 3, p. 149-150 (reprinted in Smith 1862b).

Smith, J., 1839c, On the last changes in the relative levels of the land and sea in the British Islands: Memoirs of the Wernerian Natural History Society of Edinburgh, v. 8, p. 49-89 (reprinted in Smith 1862b).

Smith, J., 1839d, Notices of the Newer Pliocene deposits in Scotland and the Western Islands: Memoirs of the Wernerian Natural History Society of Edinburgh, v. 8, p. 108-113 (reprinted in Smith 1862b).

Smith, J., 1840, On the superficial beds in the neighbourhood of Glasgow (paper read at the British Association of Science, Glasgow, Sept. 20, 1840): The Athenaeum, v. 674, p. 744.

Smith, J., 1841, On the geology of the Island of Madeira: Proceedings of the Geological Society of London, v. 3, p. 351-363 (reprinted in Smith 1862b).

Smith, J., 1846, On the scratched boulders and rocks of the coal-field of Scotland: Quarterly Journal of the Geological Society, London, v. 2, p. 33-37 (reprinted in Smith 1862b), http://dx.doi.org/10.1144/GSL.JGS.1 846.002.01-02.15.

Smith, J., 1848, The Voyage and Shipwreck of St. Paul: with Dissertations on the Sources of the Writings of St. Luke, and the Ships and Navigation of the Antients: Longman, Brown, Green, and Longmans, London, 334 p. $\left(2^{\text {nd }}\right.$ ed. $1856,3^{\text {td }}$ ed. $1866,4^{\text {th }}$ ed. 1880$)$.

Smith, J., 1850, On the occurrence of marine shells in the stratified beds below the till: Quarterly Journal of the Geological Society, v. 6, p. 386-388 (reprinted in Smith 1862b), 10.1144/GSL.JGS.1850.006.01-02.39.

Smith, J., 1862a, On a split boulder in Little Cumbrae, Western Isles: Quarterly Journal of the Geological Society of London, v. 18, p. 162-164 (reprinted in Smith 1862b), http://dx.doi.org/ 10.1144/GSL.JGS.1862.018.01-02.29.

Smith, J., 1862b, Researches in New Pliocene and Post-Tertiary Geology: John Gray, Glasgow, 199 p.

Strangways, W.T.H. Fox-, 1821, Geological sketch of the environs of Petersburg: Transactions of the Geological Society of London, v. 5, p. 392-458.

Terrisse, F.E., 1931, Réunion de la Société Helvétique des Sciences Naturelles, Neuchâtel les 24, 25, et 26 juillet 1837: Bulletin de la Société Neuchâteloise des Sciences Naturelles, v. 56(1), p. 85-102.

Tyndall, J., 1861, On the absorbtion and radiation of heat by gases and vapours, and on the physical connex- ion of radiation, absorbtion, and conduction-the Bakerian Lecture: Philosophical Magazine (series 4), v. 22, p. 169-194, 273-285 (reprinted with commentary in Archer, D., and Pierrehumbert, R.T., eds., The Warming Papers: The Scientific Foundation for the Climate Change Forecast: WileyBlackwell, Oxford, p. 21-44).

Tyndall, J., 1863, On the radiation through the Earth's atmosphere: Philosophical Magazine (series 4), v. 25, p. 200-206.

Voigt, J.K.W., 1785, Drei Briefe über die Gesteinslehre [Three essays on teaching about rocks]: Weimar, $55 \mathrm{p}$.

Wegener, A., 1929, The Origin of Continents and Oceans: Translated from the fourth [1929] revised German edition by John Biram, 1966: Dover, New York, $246 \mathrm{p}$.

Wegmann, E., 1969, Changing ideas about moving shorelines, in Schneer, C.J., ed., Toward a History of Geology: M.I.T. Press, Cambridge, MA, p. 386-414.

White, G.W., 1970, Announcement of glaciation in Scotland by William Buckland (1784-1856): Journal of Glaciology, v. 9, p. 143-145.

Woodward, H.B., 1883, Dr. Buckland and the glacial theory: Midland Naturalist, v. 6, p. 225-229.

Woodward, H.B., 1907, The History of the Geological Society of London: The Geological Society, London, 336 p. (reprinted in 1978 by Arno Press, New York).

Worsley, P., 2006, Jens Esmark, Vassryggen and early glacial theory in Britain: Mercian Geologist, v. 16, p. 161-172.

Worsley, P., 2008, Esmark's end moraine and the glacial theory from a British perspective: Earth Sciences History, v. 27, p. 12-30.

Wrede, E.G.F., 1804, Geognostische Untersuchungen über die Südbaltischen Länder, besonders über das untere Odergebiet; nebst einer Betrachtung über die allmählige Veränderung des Wasserstandes auf der nordlichen Halbkügel der Erde und deren physische Ursachen [Geognostical investigations of the south Baltic region, particularly the area of the lower Oder River; in addition to a consideration of gradual variations in sea level in the northern hemisphere and their physical origin]: Berlin, 390 p.

Wright, G.F., 1898, Agassiz and the Ice Age: The American Naturalist, v. 32, p. 165-171.

Zittel, K.A., von, 1901, History of Geology and Palaeontology to the End of the Nineteenth Century (English translation by M.M. Ogilvie-Gordon): Walter Scott, Patternoster Square, London, 562 p. 


\section{ACKNOWLEDGEMENT}

Cees van Staal provided expert nautical advice regarding the shipwreck of St.

Paul.

\section{CORRECTION}

In my column on Conrad Gebelein (Geoscience Canada, v. 41(2), p.

105-117), I incorrectly wrote that Holocene stromatolites were discovered in Hamelin Pool (Shark Bay, Western Australia) by Dick Chase, while working as an assistant to Phil Playford (Wapet). In fact, the structures were discovered by Playford in 1954, while Chase, in 1955, was the one who recognized their similarity to ancient stromatolites. 